\title{
Geology of Petroleum and Coal Deposits in the \\ North China Basin, \\ Eastern China
}

U.S. GEOLOGICAL SURVEY BULLETIN 1871 



\section{Geology of Petroleum and Coal Deposits in the North China Basin, Eastern China}

By K.Y. LEE

A synthesis of the literature clarifying the genesis and occurrence of petroleum and coal deposits in the North China basin 


\section{DEPARTMENT OF THE INTERIOR MANUEL LUJAN, Jr., Secretary \\ U.S. GEOLOGICAL SURVEY \\ Dallas L. Peck, Director}

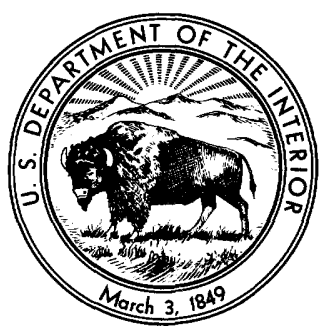

Any use of trade, product, or firm names in this publication

is for descriptive purposes only and does not imply

endorsement by the U.S. Government

For sale by the

Books and Open-File Reports Section

U.S. Geological Survey

Federal Center, Box 25425

Denver, CO 80225

Library of Congress Cataloging in Publication Data

Lee, K. Y.

Geology of petroleum and coal deposits in the North China basin, eastern China.

(U.S. Geological Survey bulletin ; 1871)

Bibliography: $p$.

Supt. of Docs. no. : 1 19.3:1871

1. Geology-China. 2. Petroleum-Geology-China. 3. Coal-Geology-

China. I. Title. II. Series. III. Series: U.S. Geological Survey bulletin ; 1871.

QE75.B9 no. $1871 \quad 557.3 \mathrm{~s}$

[QE294] [553.2' $\left.4^{\prime} 0951\right]$ 


\title{
CONTENTS
}

\author{
Abstract 1 \\ Introduction $\mathbf{2}$ \\ Regional Setting 5 \\ Stratigraphy $\mathbf{5}$ \\ Pre-Tertiary 5 \\ Tertiary 6 \\ Paleogene 6 \\ Neogene 8 \\ Structure and Evolution of the Basin 8 \\ Petroleum and Coal Deposits 11 \\ Petroleum 11 \\ General Statement 11 \\ Jizhong Depression 12 \\ Source Rocks 13 \\ Reservoir Rocks 13 \\ Traps and Seals $\mathbf{1 7}$ \\ Dongpu-Kaifeng Depression 17 \\ Source Rocks 18 \\ Reservoir Rocks 19 \\ Traps and Seals 21 \\ Huanghua Depression 21 \\ Source Rocks 22 \\ Reservoir Rocks 22 \\ Jiyang Depression 22 \\ Source Rocks 23 \\ Reservoir Rocks 23 \\ Bozhong Depression 24 \\ Source Rocks $\mathbf{2 4}$ \\ Reservoir Rocks 27 \\ Liaodong Wan-Liao He Depression \\ Source Rocks $\mathbf{2 8}$ \\ Reservoir Rocks 29 \\ Potential 30 \\ Coal 30 \\ General Statement $\mathbf{3 0}$ \\ Occurrence 31 \\ Potential 31 \\ Summary and Conclusions $\mathbf{3 4}$ \\ References Cited 34
}

\section{PLATES}

1. Geologic map of the North China basin, eastern China In pocket

2. Bedrock stratigraphy in the principal depressions of the North China basin, eastern China In pocket 


\section{FIGURES}

1. Index map of China showing the location of the study area, major Precambrian cratons, and province names $\mathbf{2}$

2. Map showing principal depressions in the North China basin, eastern China 4

3. Cross section through the central part of the North China basin $\mathbf{1 0}$

4. Isopach map showing thickness of the Earth's crust in the North China basin and adjacent areas $\mathbf{1 0}$

5. Gravity map of the North China basin and adjacent areas $\mathbf{1 1}$

6. Map showing depth to the asthenosphere in the North China basin and adjacent areas 12

7. Map showing principal structural units and oil and gas fields in the Jizhong depression 14

8. Schematic cross sections of principal oil and gas fields in the Jizhong depression 15

9. Map showing principal structural units and oil and gas fields in the DongpuKaifeng depression 18

10. Schematic cross sections of principal oil and gas fields in the Dongpu-Kaifeng depression 19

11. Map showing principal structural units and oil fields in the Huanghua depression 20

12. Schematic cross sections of principal oil fields in the Huanghua depression

13. Map showing principal structural units and oil and gas fields in the Jiyang depression 24

14. Schematic cross sections of principal oil and gas fields in the Jiyang depression 25

15. Map showing schematic cross section and principal structural units, oil and gas fields, and discovery wells of the Bozhong depression $\mathbf{2 6}$

16. Map showing principal structural units and oil fields in the Liaodong Wan-Liao He depression 28

17. Schematic cross sections of principal oil fields in the Liaodong Wan-Liao $\mathrm{He}$ depression 29

18. Map showing depth to the top of the Carboniferous and Permian strata in the principal part of the North China basin $\mathbf{3 2}$

19. Schematic profile showing the lithofacies distribution of the Carboniferous to Permian coal series in the principal part of the North China basin $\mathbf{3 3}$

\section{TABLES}

1. Orogenic cycles of China 3

2. Physical properties of the reservoirs, types of trap, and cap rocks in the prominent oil and gas fields of the Jizhong depression, North China basin 16

3. Estimated ultimate oil and gas recovery from the North China basin $\mathbf{3 1}$

4. Carboniferous and Permian stratigraphy of the North China basin $\mathbf{3 3}$ 


\section{METRIC CONVERSION FACTORS}

For readers who wish to convert measurements from the metric system of units to the inch-pound system of units, the conversion factors are listed below:

\begin{tabular}{rcl}
\hline Multiply metric unit & By & To obtain inch-pound unit \\
\hline Length & \\
micrometer $(\mu \mathrm{m})$ & $3.281 \times 10^{-6}$ & foot $(\mathrm{ft})$ \\
meter $(\mathrm{m})$ & 3.281 & foot $(\mathrm{ft})$ \\
hectometer $(\mathrm{hm})$ & 328.1 & foot $(\mathrm{ft})$ \\
kilometer $(\mathrm{km})$ & .6214 & mile $(\mathrm{mi})$ \\
& Area & \\
square meter $\left(\mathrm{m}^{2}\right)$ & 10.76 & square foot $\left(\mathrm{ft}^{2}\right)$ \\
& .0002471 & acre \\
& Volume & \\
cubic meter $\left(\mathrm{m}^{3}\right)$ & 35.31 & cubic foot $\left(\mathrm{ft}^{3}\right)$ \\
cubic kilometer $\left(\mathrm{km}{ }^{3}\right)$ & .2399 & cubic mile $\left(\mathrm{mi}^{3}\right)$ \\
& Mass & \\
megagram $(\mathrm{Mg})$ & 1.102 & ton, short $(2,000 \mathrm{lb})$ \\
& Temperature & ton, long $(2,240 \mathrm{lb})$ \\
degree Celsius $\left({ }^{\circ} \mathrm{C}\right)$ & $(9 / 5)+32$ & degree Fahrenheit $\left({ }^{\circ} \mathrm{F}\right)$ \\
\hline
\end{tabular}





\title{
Geology of Petroleum and Coal Deposits in the North China Basin, Eastern China
}

\author{
By K.Y. Lee
}

\begin{abstract}
The North China basin evolved initially from a rifted intracratonic graben system on the east-central SinoKorean platform during the Jurassic and Cretaceous Yanshanian orogeny. The basin reached its maximum stage of graben development in the Neogene owing to reactivation of the rift by the Himalayan orogeny. The basin consists of seven major depressions: Jizhong, Dongpu-Kaifeng, Huanghua, Jiyang, Bozhong, Liaodong Wan-Liao $\mathrm{He}$, and Linqing. The Linqing, however, is currently nonproductive with respect to petroleum and coal. Within the basin, geophysical data indicate that extensional rifting is still active today.
\end{abstract}

At the end of the Early Proterozoic, after consolidation of the Precambrian crystalline basement, the site of the present-day North China basin was tectonically relatively stable from the Middle Proterozoic to the early Mesozoic. During that period, the Archean and Early Proterozoic basement was affected chiefly by epeirogenic movements in association with the sedimentation of littoral to neritic marine and continental platform carbonate and detrital sedimentary sequences of Middle to Late Proterozoic, Cambrian to Middle Ordovician, and Late Carboniferous to Permian ages. From the beginning of the Late Ordovician to the end of the Early Carboniferous, the sedimentary cover of the platform was subjected to extensive weathering and a long period of erosion. In the

Manuscript approved for publication August 23, 1988. Published posthumously.
North China region, major extensional tectonism began with the Late Triassic Indosinian orogeny, continued into the Jurassic and Cretaceous Yanshanian orogeny, and culminated in the Miocene Himalayan orogeny. As a result, the present form of the basin developed from block faulting along north-northeast, northeast, and northwest trends. Of these, faulting along the north-northeast trend was the most active and controlled the sedimentation of the nonmarine basin fill. During the late Eocene to early Oligocene Himalayan orogeny, development and enlargement of the north-northeast-trending fault blocks were extensive and associated locally with igneous activity. Throughout the basin, listric-normal growth faults were tilted along gravity-sliding fault planes during sedimentation. Of the six petroleum-producing depressions described in this report, the Bozhong, Dongpu-Kaifeng, and Liaodong Wan-Liao He depressions are true grabens bounded by normal faults. The syntectonic deposits of the North China basin consist of sedimentary rocks of fluvial, deltaic, and lacustrine origin. Within the sedimentary sequences, beds of fine-grained rocks became source and cap rocks, and beds of medium- to coarsegrained rocks became reservoir rocks for oil and gas deposits.

The stratigraphic interval below the minimum burial depth for the generation of petroleum ranges from 400 meters thick in the lower reach of the Liao $\mathrm{He}$ to as much as 1,900 meters thick in the Jizhong depression. Most of the oil and gas deposits were generated from geothermal gradients ranging from about 40 to 50 degrees Celsius per kilometer. The major petroleum source rocks are confined to the Eocene to Oligocene Shahejie Formation. Carboniferous and Permian coal beds in the southern part of the basin provide the major supply of natural gas. The petroleum is trapped by faults, anticlines, facies changes, and unconformities. Crude oil from Tertiary source rocks is high in paraffin and low in sulfur. Current petroleum exploration is concentrated in the Jizhong, Dongpu-Kaifeng, Huanghua, Jiyang, Bozhong, and Liaodong Wan-Liao He depressions. The North China basin ranks second in petroleum production, after the Songliao basin. Most of the North China basin production is from the Middle and Late Proterozoic and Ordovician carbonate buried-hill reservoirs in the Jizhong, Jiyang, and Liaodong Wan-Liao He depressions and from Tertiary delta-front and channel sandstone reservoirs. The ultimate recoverable oil and gas reserves from the basin are estimated to be 11.251 billion barrels of oil and 8.425 trillion cubic feet of gas. Of the North China basin depressions, the jiyang ranks first in petroleum production, followed by the Jizhong.

The thickest good-quality coal beds are in the Benxi and Taiyuan Formations of Late Carboniferous age and in the Shanxi, the lower part of the Shihezi, and the upper part of the Shihezi Formations of Permian age. The coal reserves of the North China basin are estimated by the author to be 170 billion tons, or about 41 percent ( 411.3 billion tons) of the coal reserves in the North China region. Because the coal beds in the basin are deeply buried (more than 1,800 


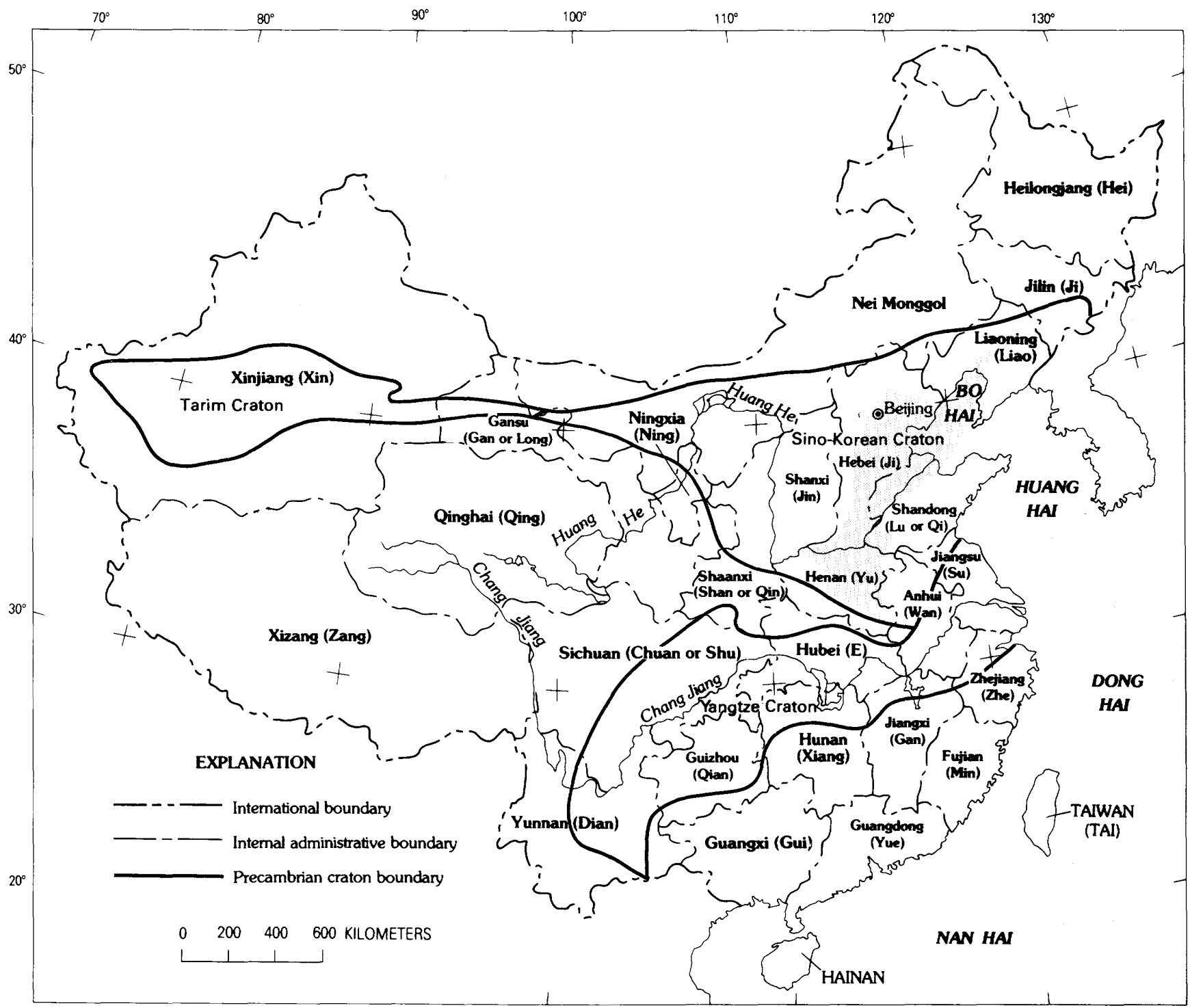

Figure 1. Location of the study area (shaded), major Precambrian cratons (modified from Lee, 1970), and province names (alternative names in parentheses) in China.

meters), most of the potentially mineable coal is excluded from coal resource consideration. In the years ahead, underground coal-mining activities near the border of the North China basin will be more extensive.

\section{INTRODUCTION}

The North China basin is located in the east-central Sino-Korean platform and evolved from an intracratonic rift system during the Mesozoic Yanshanian and Cenozoic Himalayan orogenies (fig. 1, table 1; Huang and others, 1980, p. 32-35; Ma, Liu, and Su, 1984). Most of the basin is now geographically subaerial, but a northeastern section extends partially offshore in the Bo Hai region. The basin is about $1,200 \mathrm{~km}$ in length from the lower Liao He to the city of Kaifeng and has a maximum width of about $450 \mathrm{~km}$ (Ma, Deng, and others, 1982, pl. 1). From the northeast to the southwest, the basin includes the Liaodong Wan-Liao He, Bozhong, Jiyang, Huanghua, Jizhong, Linqing, and Dongpu-Kaifeng depressions. Of these, the Linqing is currently commercially nonproductive with respect to petroleum and coal resources. The geology of the Linqing depression is similar to that of the other six petroleumproducing depressions. However, the Linqing depression is located in an area administered by three different provinces (Shandong, Hebe, and Henan), and the exploration and development of petroleum resources have been impeded $(\mathrm{Li}$ Desheng, oral commun., 1988). Discussion of petroleum and coal deposits is confined to the six producing depressions (fig. 2). The basin is bounded on the north by the Yan 
Table 1. Orogenic cycles of China

[Modified from Huang and others, 1980, table 4; Yang and others, 1986, table 20.1]

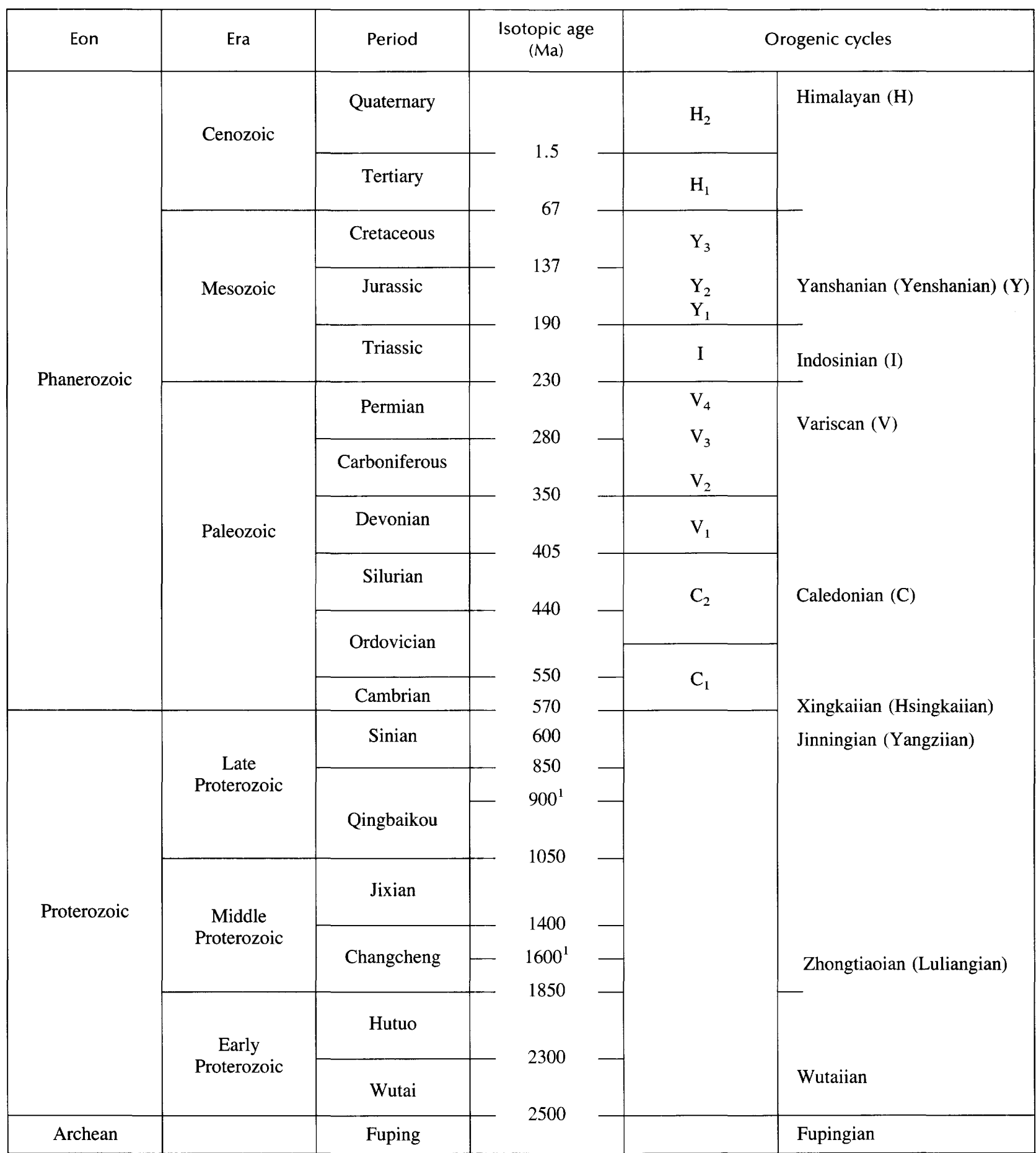

${ }^{1}$ Boundary ages of the Proterozoic recommended by IUGS Stratigraphic Commission (1982). 


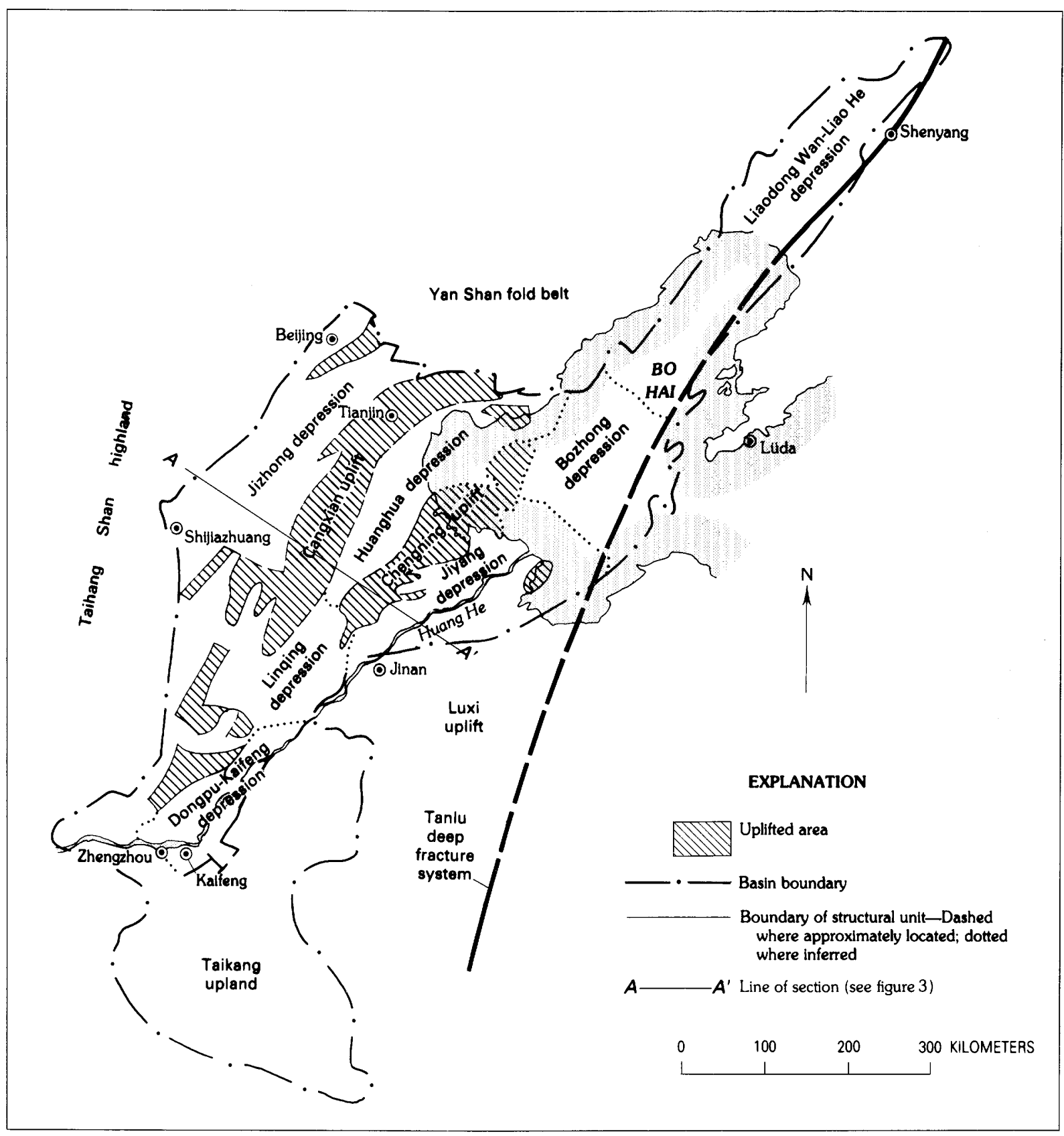

Figure 2. Principal depressions in the North China basin, eastern China (modified from Wong and others, 1983).

Shan fold belt, on the south by the Taikang upland in central Henan province, on the west by the Taihang Shan highland, and on the east by the Luxi uplift and the Tanlu deep fracture system, west of the Liaodong Bandao (figs. 1, 2; pl. 1). The basin is about $213,000 \mathrm{~km}^{2}$ in area and has been filled with about $836,000 \mathrm{~km}^{3}$ of strata ranging in age from Late Proterozoic to Cenozoic (Wang and others, 1983, table 4-10-2).

Petroleum and coal resources are substantial in the North China basin. Since the 1950's, the petroleum deposits of the basin have been extensively explored and developed.
During the past decade, petroleum production from Archean, Proterozoic, Paleozoic, and Tertiary reservoirs in the basin ranked second after the Songliao basin in Chinese petroleum output. Coal deposits in the basin are located in Carboniferous to Permian and Jurassic to Cretaceous sedimentary sequences. Carboniferous and Permian coal has been mined extensively around the basin margin in Shandong, Hebei, and Henan provinces since the early part of this century. The current status of these coal mines is not known. 
A regional synthesis of the geology of the North China basin includes a perspective on the geologic factors controlling the petroleum and coal deposits of this area. The petroleum and coal geology of the basin has been well documented in numerous Chinese and English publications.

The Pinyin system from the Gazetteer of the People's Republic of China (Defense Mapping Agency, 1979) is used for Chinese name transliteration, and the Chinese dictionary (Wu and others, 1978) is used for those names not listed in the Gazetteer.

\section{REGIONAL SETTING}

The North China basin includes most of the Bo Hai offshore area and parts of the administrative provinces of Hebei, Shandong, Anhui, Henan, and Liaoning (fig. 1, pl. 1). The Archean and Early Proterozoic crystalline basement of the North China basin is one of the most stable cratonic units of China. Consolidation of the basement occurred at the end of Early Proterozoic time, about 1,850 Ma (table 1; Ma, Zhang, and others, 1984; Wang and Qiao, 1984). Drilling records indicate that Middle and Late Proterozoic platform sedimentary rocks of the Changcheng through Sinian Systems attain a maximum thickness in the Jizhong depression (pl. 2). The other depressions contain thin Middle and Late Proterozoic strata except in the Jiyang depression, where Proterozoic rocks are completely missing (Hao and Zhang, 1984). Most of these Precambrian rocks are unconformably overlain by Cambrian and Ordovician marine carbonate sequences, Carboniferous and Permian marine and continental coal-bearing sequences, Jurassic and Cretaceous continental coal-bearing sequences, and, locally, Jurassic and Cretaceous volcanic rocks. Throughout the basin, Paleozoic and Mesozoic rocks are unconformably overlain by thick Tertiary strata.

From the beginning of the Late Ordovician to the end of the Early Carboniferous, the North China basin was part of an ancient emergent landmass that was subjected to intense weathering and erosion. As the basin subsided during the Late Carboniferous to the Early Permian, the area was covered by shallow-marine and shoreline deposits. During Early Jurassic time, the initial depositional framework of the North China basin was established by a northeast-trending rift system and localized calc-alkaline and granitic intrusions, a northeast-trending faulted Taihang Shan highland on the west, and a rejuvenated pre-Mesozoic Tanlu deep fracture system on the east. The present-day form of the basin was created by intense rifting in early Tertiary time, during which the basin received thick syntectonic deposits that contained petroleum source rocks (Ma. Liu, and Su, 1984).

\section{STRATIGRAPHY}

The stratigraphy of the North China basin presented here is based chiefly on drilling records. A summary of the stratigraphy of the basin, for all but the Quaternary deposits, is shown in plate 2. Quaternary deposits, about 175 to $727 \mathrm{~m}$ thick, rest disconformably on the bedrock throughout the basin (Regional Stratigraphic Editorial Section of the Hebei Province and the Tianjin Region, 1979b).

\section{Pre-Tertiary}

The pre-Tertiary stratigraphic sequences consist of sedimentary and metamorphic rocks of Middle and Late Proterozoic through Mesozoic age, shown in plate 2 (excluding Archean and Early Proterozoic crystalline basement rocks).

The Archean and Early Proterozoic crystalline basement rocks of the basin consist of Archean gneissic granite, granulite, amphibolite, and gneiss, as well as Early Proterozoic greenschist, quartzite, phyllite, slate, dolomitic marble, marble, quartz keratophyre, and metamorphosed conglomerate and basic volcanic rocks ( $\mathrm{Ma}$, Zhang, and others, 1984, p. 225-236; Wang and Qiao, 1984, p. 600-601). This crystalline terrane is unconformably overlain by platform carbonate and ferruginous sandstone units of Middle and Late Proterozoic Changcheng-JixianQingbaikou and Sinian age.

The Changcheng-Jixian-Qingbaikou sedimentary cover consists, in the lower part, of sandstone, quartzite, arenaceous limestone, siltstone, shale, dolomite, and limestone containing a basal conglomerate consisting locally of basalt and andesite clasts; in the middle part, of cherty bituminous dolomite, stromatolitic and argillaceous dolomite that has a basal breccia; and, in the upper part, chiefly of shale, algal dolomite, limestone, and some marble and sandstone. The ranges of thickness of the Middle and Late Proterozoic sedimentary sequences in the principal depressions of the basin are 300 to $3,500 \mathrm{~m}$ in the Jizhong, 0 to $800 \mathrm{~m}$ in the Dongpu-Kaifeng, 0 to $600 \mathrm{~m}$ in the Huanghua, 0 to $1,500 \mathrm{~m}$ in the Liaodong Wan-Liao $\mathrm{He}$, and 0 to $500 \mathrm{~m}$ in the Bozhong. Generally, Proterozoic sedimentary sequences are absent in the Jiyang (Hao and Zhang, 1984).

The Sinian System as used in this report is assigned to the uppermost part as used in the Late Proterozoic (Chinese Academy of Geological Sciences, 1982, table 1). Wang and Qiao (1984, table 3) defined the Sinian System in China as a stratigraphic unit deposited between $800 \mathrm{Ma}$ and $600 \mathrm{Ma}$ and designated a 3,143-m-thick type section in the Liaodong Bandao of the Liaoning province. Wang and Qiao (1984, p. 605) reported that thick Sinian sedimentary sequences occur around the northern and southern borders of the basin. Drilling in the Jizhong depression, where Sinian sedimentary rocks are present, penetrated 200 to $300 \mathrm{~m}$ of light-gray to dark-gray siliceous dolomite, dolomitic limestone, and limestone intercalated with blackishgray shale and brownish-purple sandstone. The author assigns this unit to the Sinian System, but it might belong to the Qingbaikou System. 
Lower Paleozoic strata of the North China basin are represented by Cambrian and Ordovician carbonate units that are widely distributed within the basin. The Cambrian rocks consist, in the lower part, of dark-gray to purple shale and limestone and, in the upper part, of dark-gray to yellowish-gray oolitic, thin-bedded limestone intercalated with dark-greenish-gray and purple shale. The Cambrian rocks range in thickness from 60 to $750 \mathrm{~m}$. The Ordovician rocks rest conformably on the Cambrian strata and are made up of light-gray to dark-gray crystalline and dolomitic limestone intercalated with brownish-gray to gray dolomite and blackish-gray argillaceous, cherty, thin-bedded, conodont-bearing limestone. The Ordovician rocks range in thickness from 60 to $800 \mathrm{~m}$.

The Upper Paleozoic strata of the basin consist of an undifferentiated Carboniferous to Permian coal-bearing sequence, which lies unconformably on Ordovician strata. The lower parts of the sequence consist of bluish-gray to black mudstone and gray fine- to medium-grained quartzose sandstone intercalated with very thin to thick coal beds and small amounts of limestone lenses. The upper part of the Carboniferous to Permian sequence consists of light-gray conglomeratic sandstone and grayish-green to black mudstone intercalated with black carbonaceous mudstone and thin to thick coal beds, except in the Huanghua and Jiyang depressions, where coal beds are generally absent. Fossil flora and fauna are abundant. The upper Paleozoic unit ranges in thickness from 160 to $1,060 \mathrm{~m}$.

Mesozoic strata of the basin are represented by an undifferentiated Jurassic to Cretaceous continental sequence, which lies unconformably on the Carboniferous to Permian strata. In the lower part of the sequence, the continental strata consist of light-brown, grayish-green, and dark-purplish-red sandy mudstone. Purplish-red to grayishgreen sandstone is intercalated with coal beds in the Huanghua and Bozhong depressions and with oil shale in the Liaodong Wan-Liao He depression. The middle part of the sequence consists of light-gray to grayish-green sandstone, dark-purple, grayish-green, and brown mudstone, and dark-gray to black shale intercalated with coal beds and volcanic rocks in the Jizhong, Bozhong, and Liaodong Wan-Liao He depressions. The upper part of the sequence consists of purplish-red to brownish-red sandstone, conglomeratic sandstone, and blackish-gray to dark-purple mudstone intercalated with volcanic rocks in the Huanghua and Jiyang depressions. Plant fossils are abundant. The Mesozoic unit ranges in thickness from 190 to $1,600 \mathrm{~m}$.

\section{Tertiary}

During the past decade the Tertiary strata of the basin have been studied in detail by using the results obtained from extensive seismic work and exploratory drilling. The Tertiary sequence consists, in the Paleogene, of the Eocene
Kongdian Formation, the Eocene to Oligocene Shahejie Formation, and the Oligocene Dongying Formation and, in the Neogene, of the Miocene Guantao Formation and the Miocene to Pliocene Minghuazhen Formation.

\section{Paleogene}

Throughout the basin, the Kongdian Formation unconformably overlies the Jurassic to Cretaceous strata. In the Jizhong and Dongpu-Kaifeng depressions, this formation is undivided and consists chiefly of fluvial and shallow lake deposits of light-brown, dark-red, dark-brown, and black mudstone and sandstone. Conglomeratic sandstone is found locally in the Jizhong depression. In the remaining depressions, the Kongdian Formation is divided, in ascending order, into the third, second, and first members. In the Huanghua depression, the third member is composed of 350 to $440 \mathrm{~m}$ of brown to reddish-brown sandy mudstone, basaltic flows, and a basal conglomeratic sandstone that grades upward into grayish-brown to reddish-brown mudstone, siltstone, and sandy mudstone. Approximately 300 to $500 \mathrm{~m}$ of red sandstone, mudstone, and basal conglomeratic sandstone interbedded with basaltic flows make up the third member in the Jiyang, Bozhong, and Liaodong Wan-Liao $\mathrm{He}$ depressions. The second member of the Kongdian Formation consists of 120 to $440 \mathrm{~m}$ of dark-gray to dark-grayish-green shale intercalated with greenish-gray shale, oil shale, and thin-bedded sandstone in the Huanghua depression and of about 500 to $600 \mathrm{~m}$ of gray mudstone and sandstone intercalated with carbonaceous shale, oil shale, and thin coal beds in the Jiyang, Bozhong, and Liaodong Wan-Liao He depressions. Freshwater gastropods are found in the second member of the formation throughout the Jiyang depression. The youngest member of the Kongdian Formation in the Huanghua depression is made up of 90 to $700 \mathrm{~m}$ of dark-purple to reddish feldspathic sandstone and mudstone intercalated with grayish-green sandy shale in the upper part throughout the formation, and local beds of conglomeratic sandstone containing basalt and gypsumbearing mudstone. About 300 to $500 \mathrm{~m}$ of red sandstone and mudstone form the first member of the Kongdian Formation in the Jiyang, Bozhong, and Liaodong Wan-Liao He depressions.

The Shahejie Formation consists chiefly of shallow to deep lake deposits and, in ascending order, is divided into the fourth, third, second, and first members. In the Jizhong depression, the fourth member comprises 90 to $1,000 \mathrm{~m}$ of light-gray to dark-gray mudstone intercalated with basaltic flows, light-gray to gray sandstone, and conglomeratic sandstone that grades upward into gray to dark-gray mudstone and white gypsum beds intercalated with gray thinbedded siltstone and purplish-red mudstone. In the DongpuKaifeng depression, the fourth and third members are 
undifferentiated and consist of 400 to $2,000 \mathrm{~m}$ of gray to dark-gray and purplish-red mudstone and siltstone intercalated with salt beds, gypsum beds, and shale. In the Huanghua depression, the fourth member of the Shahejie comprises 60 to $510 \mathrm{~m}$ of bluish-gray to dark-gray gypsum beds and grayish-green mudstone intercalated with siltstone and some sandstone. In the Jiyang, Bozhong, and Liaodong Wan-Liao He depressions, the fourth member of the Shahejie Formation generally consists, in the lower part, of 150 to $500 \mathrm{~m}$ of red mudstone; in the middle part, of 100 to 300 $\mathrm{m}$ of bluish-gray mudstone intercalated with gypsum beds and salt beds; and, in the upper part, of 100 to $150 \mathrm{~m}$ of gray mudstone intercalated with reef limestone, dolomite, and oil shale.

In the Jizhong depression, the third member of the Shahejie is made up of 70 to $1,000 \mathrm{~m}$ of gray to dark-gray mudstone, gray fine-grained sandstone, black oil shale, light-brown dolomitic limestone, and dolomite grading upward into gray to dark-gray mudstone intercalated with sandy mudstone, light-gray thin-bedded sandstone, and black oil shale. Plant fossils and ostracodes are abundant. In the Huanghua depression, the third member of the Shahejie comprises 100 to $1,000 \mathrm{~m}$ of dark-gray to black mudstone intercalated with oil shale, sandstone, shale, gray limestone, marl, and reef limestone. The third member of the Shahejie in the Jiyang, Bozhong, and Liaodong Wan-Liao He depressions consists, in the lower part, of 100 to $150 \mathrm{~m}$ of gray mudstone intercalated with sandstone, oil shale, and basal conglomeratic sandstone; in the middle part, of 400 to $600 \mathrm{~m}$ of gray to dark-gray mudstone intercalated with siltstone, sandstone, and dolomite; and, in the upper part, of 300 to $400 \mathrm{~m}$ of gray fossiliferous mudstone intercalated with sandstone.

The second member of the Shahejie in the Jizhong depression consists chiefly of 150 to $370 \mathrm{~m}$ of light-gray calcareous thin- to thick-bedded sandstone intercalated with purplish-brown, reddish-brown, and grayish-green mudstone. In the northern part of the Jizhong, the lower part of the second member is represented by thin-bedded shale, oil shale, dark-gray reef limestone, and dolomitic limestone and marl. These carbonate rocks grade laterally into lightgray sandstone and reddish-purple mudstone. In the Dongpu-Kaifeng depression, the second member of the Shahejie comprises 400 to $850 \mathrm{~m}$ of light-gray to gray calcareous sandstone and reddish-brown to dark-purple mudstone intercalated with gray limestone and gypsumbearing mudstone. In the Huanghua depression, the second member of the Shahejie is made up of 10 to $300 \mathrm{~m}$ of gray to dark-gray fossiliferous dolomite and purplish-red mudstone that grades laterally into calcareous siltstone and lenticular sandstone that contains basal conglomeratic sandstone. In the Jiyang, Bozhong, and Liaodong Wan-Liao He depressions, the second member of the Shahejie consists of 100 to $250 \mathrm{~m}$ of variegated sandstone and siltstone interca- lated with carbonaceous shale and dolomite. Gastropods are abundant in the second member throughout the basin.

The first member of the Shahejie in the Jizhong depression consists of 100 to $700 \mathrm{~m}$ of reddish-brown to brown mudstone intercalated with grayish-green to purplish-gray mudstone and light-gray thin-bedded sandstone. In the Dongpu-Kaifeng depression, the first member of the Shahejie comprises, in the lower part, 170 to $450 \mathrm{~m}$ of mudstone intercalated with salt beds and, in the upper part, mudstone intercalated with oil shale, reef limestone, and siltstone. In the Huanghua depression, the first member of the Shahejie is made up of 30 to $500 \mathrm{~m}$ of dark-gray to gray calcareous oil shale, shale, gray limestone, and reef limestone intercalated with grayish-green mudstone and locally with calcareous sandstone. In the Jiyang, Bozhong, and Liaodong Wan-Liao He depressions, the first member of the Shahejie is composed of 200 to $400 \mathrm{~m}$ of gray mudstone intercalated with oil shale and limestone containing abundant gastropods and ostracodes.

The Dongying Formation consists of shallow-lake, deltaic, and fluvial deposits, which throughout the basin are unconformably overlain by the Miocene Guantao Formation. Generally the Dongying is divided, in ascending order, into the third, second, and first members in the Jizhong, Jiyang, Bozhong, and Liaodong Wan-Liao He depressions. The Dongying in the Dongpu-Kaifeng depression is undivided, but, in the Huanghua depression, the Dongying is divided into five members.

In the Dongpu-Kaifeng depression, the Dongying Formation consists of 100 to $1,000 \mathrm{~m}$ of red siltstone, sandstone, and mudstone intercalated with dark carbonaceous mudstone. In the Huanghua depression, the fifth member of the Dongying is composed of 60 to $300 \mathrm{~m}$ of dark-gray to black mudstone intercalated with grayish-green oil shale; the fourth member, of 150 to $350 \mathrm{~m}$ of gray to dark-gray mudstone intercalated with light-gray to gray sandstone; the third member, of 50 to $240 \mathrm{~m}$ of light-gray to grayish-green sandstone intercalated with gray, dark-gray, and grayish-green sandy mudstone; the second member, of 50 to $330 \mathrm{~m}$ of gray to dark-gray mudstone intercalated with light-gray to grayish-green siltstone and a small amount of very fine grained sandstone; and the first member, of 150 to $380 \mathrm{~m}$ of light-gray to grayish-green fine- to mediumgrained sandstone intercalated with conglomeratic sandstone and mudstone. Fossils of fish, plants, ostracodes, gastropods, pollen, and spores are abundant in this unit.

In the Jizhong depression, the third member of the Dongying consists of 45 to $400 \mathrm{~m}$ of reddish-brown to brown mudstone intercalated with gray to reddish-brown thin-bedded sandstone, calcareous shale, and oil shale. In the Jiyang, Bozhong, and Liaodong Wan-Liao He depressions, the third member of the Dongying comprises 150 to $800 \mathrm{~m}$ of gray to dark-gray carbonaceous mudstone intercalated with variegated sandstone. The second member of the Dongying in the Jizhong depression is made up of 200 
to $300 \mathrm{~m}$ of gray, reddish-brown, and greenish-gray mudstone intercalated with grayish-brown, brown, and lightgray sandstone, black shale, and brownish-gray oil shale. In the Jiyang, Bozhong, and Liaodong Wan-Liao He depressions, the second member of the Dongying consists of 200 to $300 \mathrm{~m}$ of variegated mudstone intercalated with gray fine- to coarse-grained sandstone containing abundant gastropods. The first member of the Dongying in the Jizhong depression comprises 40 to $371 \mathrm{~m}$ of reddish-purple, reddish-brown, and purple mudstone intercalated with gray, grayish-green, grayish-brown, and purplish-gray mudstone and light-gray thin-bedded sandstone containing abundant fossil fauna. In the Jiyang, Bozhong, and Liaodong WanLiao He depressions, the first member of the Dongying is made up of 0 to $300 \mathrm{~m}$ of red mudstone intercalated with gray sandstone containing abundant gastropods and charophytes.

\section{Neogene}

The Guantao Formation is represented chiefly by fluvial and deltaic sequences that are distributed throughout the principal depressions of the basin (pl. 2). The Guantao is present in the western part of the Jizhong depression and consists of $1,000 \mathrm{~m}$ of brown to reddish-brown mudstone; light-gray, grayish-green, and light-yellow very fine to medium-grained sandstone intercalated with gray, grayishgreen, brown, and purplish-gray thin-bedded mudstone; and light-gray medium- to coarse-grained basal sandstone and conglomeratic sandstone. Pollen, spores, and plant fossils are abundant. In the Dongpu-Kaifeng depression, the Guantao is made up of 200 to $300 \mathrm{~m}$ of light-gray sandstone intercalated with mudstone and a basal conglomerate. In the Huanghua depression, the Guantao consists, in the lower part, of light-gray thick-bedded sandstone intercalated with grayish-green thin-bedded mudstone and siltstone containing abundant ostracodes and fossil plants; in the middle part, of light-grayish-green siltstone intercalated with crossbedded conglomeratic sandstone and grayish-green mudstone; and, in the upper part, of light-gray and grayishgreen, crossbedded sandstone. The thickness of this unit ranges from 200 to $600 \mathrm{~m}$. In the Jiyang, Bozhong, and Liaodong Wan-Liao He depressions, the lithologic description of the Guantao is based on subsurface drilling data obtained from the Jiyang depression and the Chengning area of the Hebei province (Regional Stratigraphic Editorial Section of the Hebei Province and Tianjin Region, 1979b, v. 2, p. 153) (fig. 2). As stated, the Guantao consists, in the lower part, of light-gray coarse-grained sandstone intercalated with conglomeratic sandstone and grayish-green to reddish-purple mudstone and, in the upper part, of lightgray conglomeratic sandstone intercalated with grayishgreen thin-bedded, sandy mudstone and clayey siltstone. The thickness of this unit ranges from 130 to $540 \mathrm{~m}$.
The Minghuazhen Formation conformably overlies the Guantao Formation throughout the basin and is composed of fluvial and deltaic deposits. In the Jizhong depression, the Minghuazhen is divided, in ascending order, into the second and first members. The second member in this depression is made up of 500 to $700 \mathrm{~m}$ of light-reddishbrown to yellowish-brown siltstone intercalated with grayish-green, light-gray, and grayish-yellow thin-bedded mudstone, fine- to coarse-grained sandstone, and conglomeratic sandstone. The first member consists of 300 to $600 \mathrm{~m}$ of variegated very fine to medium-grained and conglomeratic sandstone intercalated with light-gray to grayish-yellow medium- to coarse-grained sandstone and mudstone. In the Dongpu-Kaifeng depression, the Minghuazhen is undivided and comprises about $800 \mathrm{~m}$ of brownish-yellow to grayishgreen siltstone and mudstone intercalated with sandstone. In the Huanghua depression, the Minghuazhen Formation is divided, in ascending order, into the second and first members. The second member is made up of 1,000 to 1,500 $\mathrm{m}$ of reddish-brown to grayish-green thick-bedded mudstone intercalated with light-gray to grayish-green crossbedded and fine-grained sandstone. The first member comprises 400 to $800 \mathrm{~m}$ of gray to grayish-green sandstone intercalated with conglomeratic sandstone, grayish-green, reddish-brown, and reddish-purple sandy mudstone, and thin-bedded siltstone. In the Jiyang, Bozhong, and Liaodong Wan-Liao He depressions, the lithology of the Minghuazhen is described on the basis of subsurface data from the Chengning area located west of the Jiyang depression. The Minghuazhen is undivided and generally consists of 630 to $980 \mathrm{~m}$ of variegated mudstone, siltstone, and sandstone grading upward into grayish-green to yellowishbrown mudstone and siltstone intercalated with fine-grained sandstone containing calcite and iron-manganese concretions.

\section{STRUCTURE AND EVOLUTION OF THE BASIN}

Since the consolidation of the Archean and Early Proterozoic crystalline basement during the Zhongtiaoian [Luliangian] orogeny (table 1; Yang and others, 1986, table 20-1), the present-day North China basin has been tectonically relatively stable. An east-west-trending fracture system is prominent in the region. From Middle and Late Proterozoic to late Paleozoic time, the Archean and Early Proterozoic basement rocks of the basin were affected chiefly by epeirogenic movements in association with the sedimentation of littoral to neritic marine and continental platform carbonate and detrital sedimentary sequences of Middle and Late Proterozoic, Cambrian to Middle Ordovician, and Late Carboniferous to Permian age. From the beginning of the Late Ordovician to the end of the Early Carboniferous, the platform sedimentary cover was subjected to a lengthy period of extensive weathering and 
erosion. The Caledonian orogeny and the early phases of the Variscan orogeny had little effect on the landmass of the present-day North China basin. From the Late Carboniferous to the Early Permian, moderate subsidence of the basin accompanied by sea transgression produced a linear shoreline and coal-bearing sedimentary sequences. As the sea regressed in the Late Permian, the area of the present-day basin was gradually uplifted, and widespread continental coal-bearing sedimentary sequences were deposited in lowland areas (Han and Yang, 1980, p. 92-152).

The North China basin acquired its incipient depositional framework during a series of Jurassic to Cretaceous Yanshanian taphrogenic events. Regional fracture systems in the early stage of basin development trended northeast, north-northeast, and northwest. The author believes that, during an early episode of extensional tectonics (Indosinian in Late Triassic time), the Taihang Shan highland on the west side of the basin was formed by northwest-verging compressional stresses. The Tanlu deep fracture system on the east side of the basin was rejuvenated above an early compression shear zone during and following heating and thinning of the lithosphere at the time of initial rifting. The Taihang Shan highland and Tanlu deep fracture system have a north-northeast trend. The northwest-trending fracture system in the basin was formed by tensile stresses related to a northwest-southeast-oriented compressional stress field. From Late Jurassic to Early Cretaceous time, the northeast and north-northeast fracture systems, and to some extent the northwest fracture system, were enlarged by Yanshanian extensional tectonics. Taphrogenic activities occurred in association with acidic intrusives, calc-alkaline lava flows, and fault blocks throughout the North China basin. Generally, the north-northeast fracture system was active during detrital sedimentation of Jurassic and Cretaceous age and controlled the structural development of the individual depressions of the North China basin during the Cenozoic. During the late part of the Yanshanian orogeny, from Late Cretaceous to early Paleogene time, fault blocks were uplifted and broken. The blocks then subsided during regional downwarping. The absence of Upper Cretaceous and Paleocene sequences in the basin indicates that the outcrops in the basin underwent a rather long period of weathering and denudation now represented by an angular unconformity (pl. 2).

During the Cenozoic, the North China basin was subjected to intense extensional faulting and differential movement of the fault blocks, followed by regional downwarping. These structural events are documented in publications by Li Desheng $(1979,1982,1984)$, Liu and others (1981), Lin (1982), Ma, Deng, and others (1982), Li and Xue (1983), Ma and others (1983), Deng and others (1984), Ding (1984), Fei and Wang (1984), Zha (1984), and Hellinger and others (1985). The basic tectonic data and interpretations provided by these publications contributed significantly to this report.
Many Chinese geologists have recognized that tectonic patterns, established during the Mesozoic, controlled the structural development of the North China basin during Cenozoic time. In the early phase of the Himalayan orogeny from late Eocene to early Oligocene time, an extensive north-northeast-trending block-faulting system formed in the central portion of the North China basin (fig. 3). Subsequently, this graben-and-horst system expanded along the general trend of the rejuvenated north-northeast and northeast fracture systems. Ma, Deng, and others (1982, p. 105) suggested that the characteristic Paleogene structures of the basin were caused by tilted fault blocks, which formed above listric-normal faults. In the basin, half grabens are predominant; grabens, although present, are asymmetric in profile because of the different degrees of dip on their bounding faults. Paleogene syntectonic deposits of fluviolacustrine and fluviodeltaic origin reached maximum thicknesses of about $4,541 \mathrm{~m}$ in the Jizhong depression, 4,500 $\mathrm{m}$ in the Dongpu-Kaifeng depression, $5,490 \mathrm{~m}$ in the Huanghua depression, and about $5,750 \mathrm{~m}$ in the Jiyang, Bozhong, and Liaodong Wan-Liao He depressions (pl. 2). Tholeiitic basaltic flows occurred with the Paleogene sedimentation throughout the basin and attained a cumulative thickness of $550 \mathrm{~m}$ in the lower Liao He and the Bozhong (Ma, Deng, and others, 1982, p. 105). The northwesttrending fault system in the basin is oblique to the northnortheast graben trend and locally offsets the graben system. The end of the early phase of the Himalayan orogeny (table 1) is indicated by a basinwide angular unconformity between the Oligocene and Miocene strata (pl. 2).

During the Neogene, the North China basin acquired its present configuration through regional subsidence, which in general followed the tectonic grain of the Paleogene rift system. The Neogene sedimentary cover is more widespread than the Paleogene strata and has maximum thicknesses of 2,300 $\mathrm{m}$ in the Jizhong depression, 1,100 $\mathrm{m}$ in the Dongpu-Kaifeng depression, 2,900 $\mathrm{m}$ in the Huanghua depression, and about $1,520 \mathrm{~m}$ in the Jiyang, Bozhong, and Liaodong Wan-Liao He depressions (pl. 2).

Geophysical data indicate that the North China basin, particularly in the Bo Hai region, is underlain by relatively warm and highly attenuated crust and lithosphere (figs. 4-6; Ma, Liu, and Su, 1984, p. 619-620). Hellinger and others (1985) concluded that the Cenozoic depocenters in the basin coincided with the areas of thin pre-Cenozoic crust. In contrast, Quaternary subsidence appeared to Hellinger and others (1985) to have been greatest where the present thickness of the pre-Cenozoic crust is greatest. Hellinger and others (1985, p. 356) further stated that the present crustal structure, geologic history, and Cenozoic sediment fill of the basin suggest a nearly constant crustal thickness of about $40 \mathrm{~km}$ at the onset of rifting in the middle Eocene. Ma, Liu, and Su (1984, p. 619) suggested that an electrically conductive low-velocity layer underlies the basin at a depth of 15 to $20 \mathrm{~km}$. This layer may represent a transition 


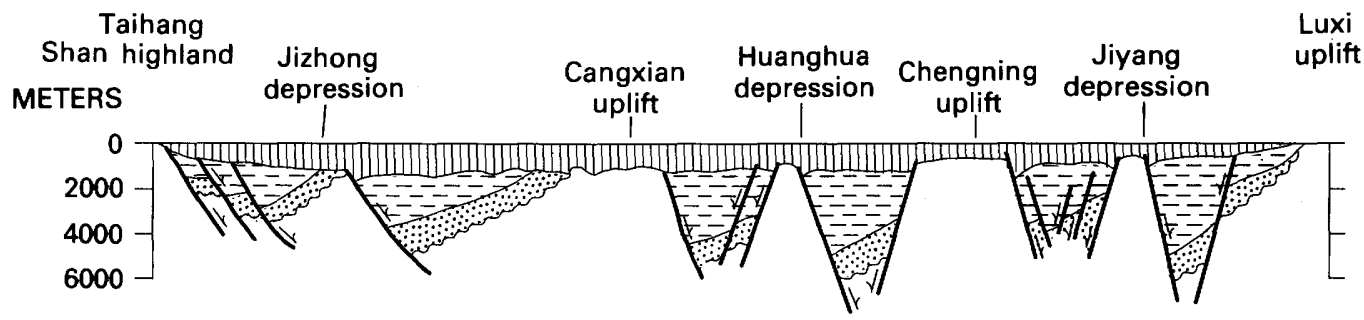

EXPLANATION

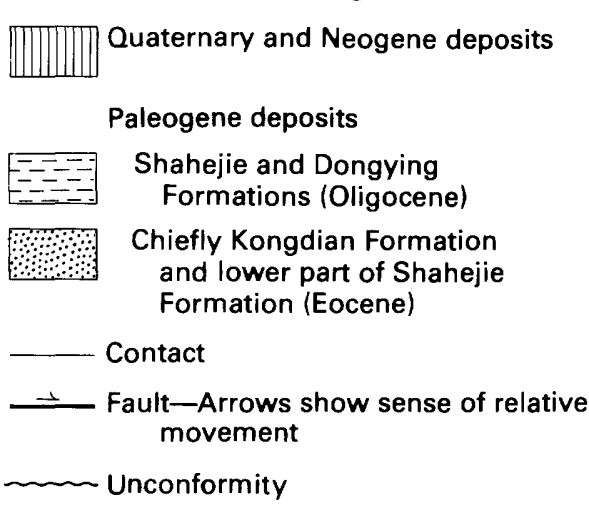

Figure 3. Cross section through the central part of the North China basin (modified from Ma, Deng, and others, 1982). Location of section shown on figure 2 and plate 1.

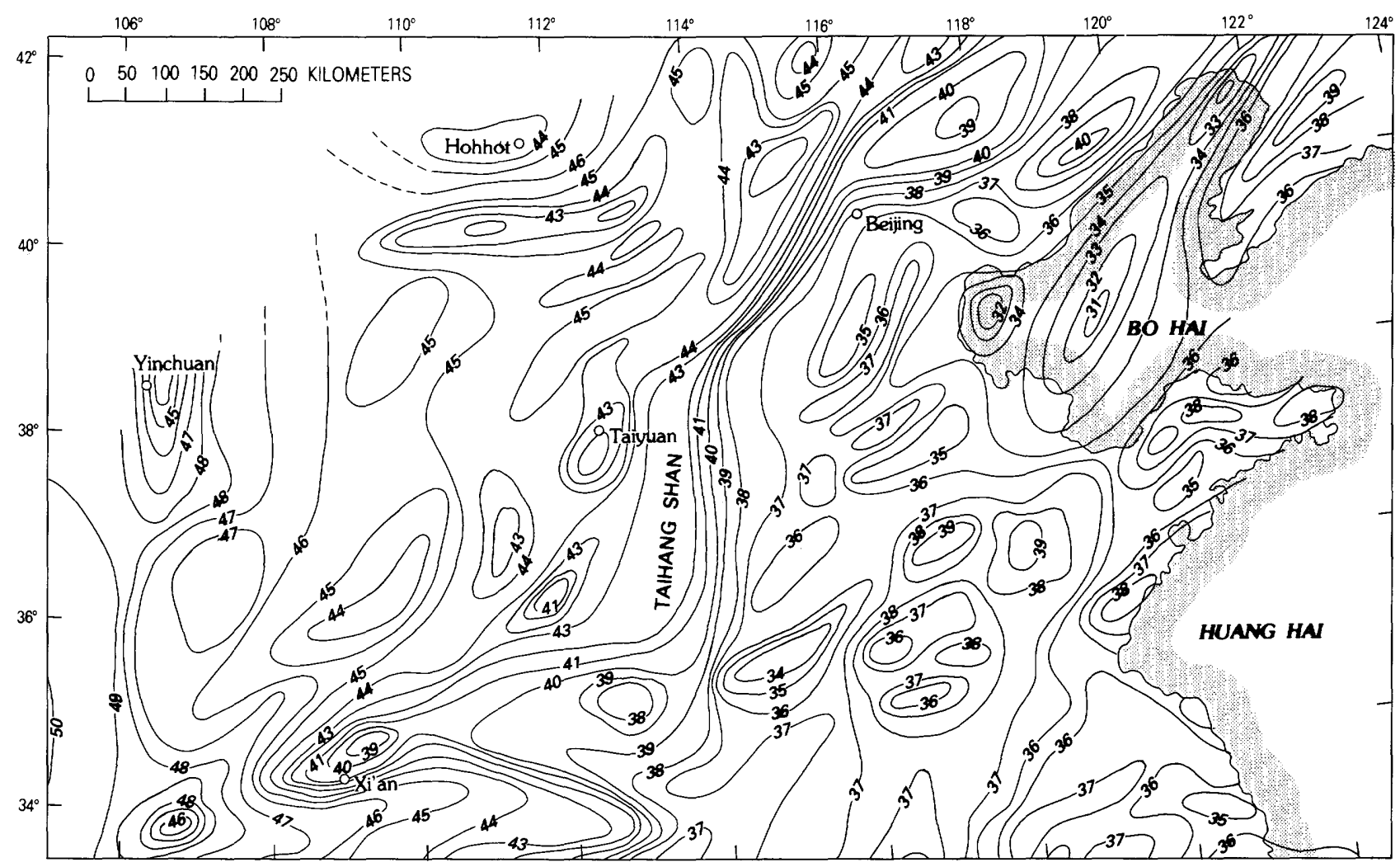

Figure 4. Thickness of the Earth's crust in the North China basin and adjacent areas (from Ma, Deng, and others, 1982). Contour interval $1 \mathrm{~km}$. 


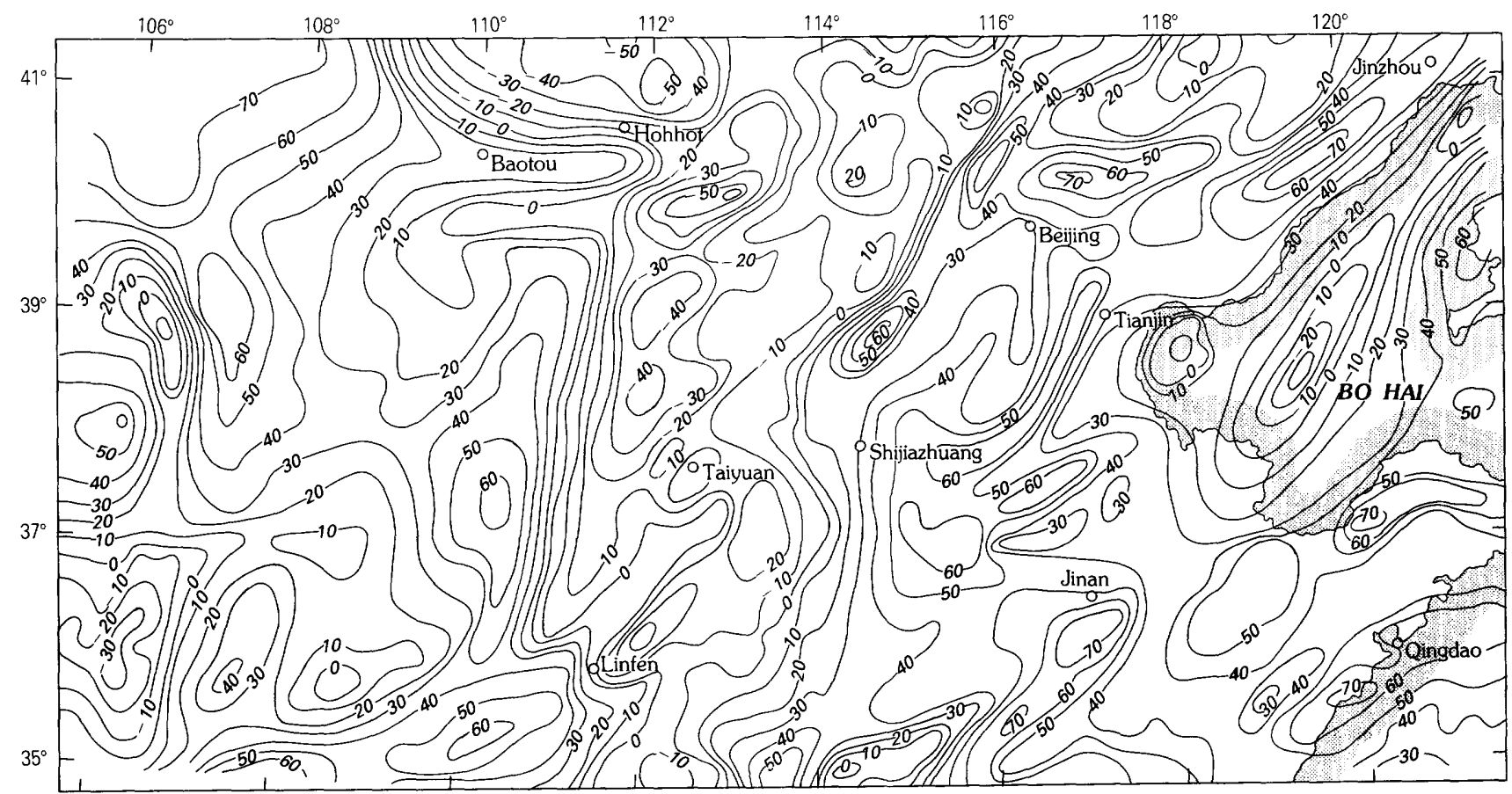

\begin{tabular}{l}
0 \\
\hline
\end{tabular}$\quad 100 \quad 200$ KILOMETERS

Figure 5. Gravity map of the North China basin and adjacent areas (from Deng and others, 1984). Contour interval 10 milligals.

zone between the brittle and ductile zones of deformation, into which normal faults in the brittle zone may be assimilated. The foci of shallow earthquakes lie above this low-velocity rigid layer, and the underlying viscoelastic lower crust deforms slowly by lateral creep during inhomogeneous mantle upwelling. Ma, Liu, and Su (1984, p. 620) further stated that the upward advection of the asthenosphere to a depth of 50 to $80 \mathrm{~km}$ was a fundamental control of extensional structures during the evolution of the North China basin.

\section{PETROLEUM AND COAL DEPOSITS}

Petroleum and coal are the most important energy resources in the North China basin. In 1961, after a systematic search in the lower reaches of the Huang $\mathrm{He}$ during the late 1950 's to early 1960 's, petroleum was discovered in Tertiary strata in the Zhanhua sag of the Jiyang depression (fig. 2, pl. 1). Production in this field began in 1962 (Meyerhoff, 1982, p. 260-261; Zhai and Zha, 1982). This field was the first of the so-called Shengli [Victory] oil and gas fields. Since then, extensive onshore drilling has led to the discovery of numerous commercial oil and gas wells in the Jiyang, Huanghua, Jizhong, DongpuKaifeng, and Liaodong Wan-Liao He depressions (fig. 2). Currently, production from the Shengli fields of the Jiyang depression ranks first in petroleum output from the North China basin. The Japan-China Oil Development Corporation began offshore exploration in the late 1960's. The Haisi field in the Minghuazhen Formation was discovered in the Bohai Wan west of the Bozhong depression in 1970 (Petroconsultants Ltd., 1981). The Japan-China Oil Development Corporation made several new discoveries of commercial oil and gas wells in the Bozhong depression from 1981 to 1984 (Petroconsultants Ltd., 1984).

Deposits of high-quality bituminous coal and anthracite of Carboniferous and Permian age and bituminous coal of Jurassic and Cretaceous age have been recorded in the basin. Commercial underground coal mines are in operation near the border of the basin, chiefly in the Hebei, Shandong, and Henan provinces.

\section{Petroleum}

\section{General Statement}

Petroleum deposits in the North China basin are located in the Jizhong, Dongpu-Kaifeng, Huanghua, Jiyang, Bozhong, and Liaodong Wan-Liao He depressions (fig. 2, pl. 2). Oil and gas production from various types of traps in the reservoirs of the basin has been generated from source rocks in the Tertiary sedimentary sequence (Masters 


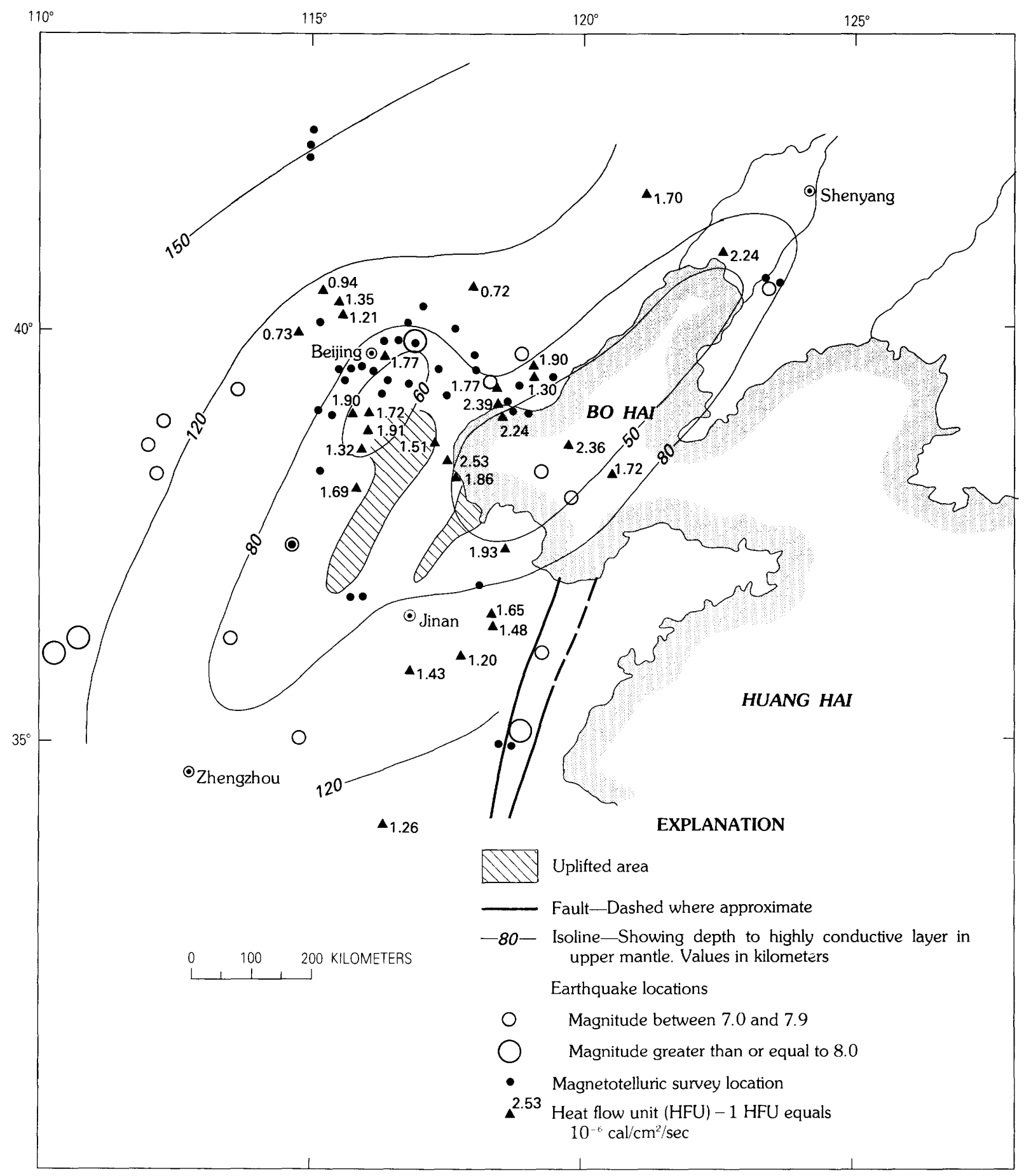

Figure 6. Depth to the asthenosphere in the North China basin and adjacent areas (from Ma, Liu, and Su, 1984).

and others, 1980; Wang and others, 1983). In addition, gas accumulations have been reported from source rocks of the Jurassic and Cretaceous strata in the Bozhong and the Liaodong Wan-Liao He depressions and from source rocks of the Carboniferous and Permian strata in the DongpuKaifeng depression. Oil and gas deposits in Middle Proterozoic (Jixian) sedimentary rocks have been reported from the northern part of the Jizhong depression.

\section{Jizhong Depression}

For the past decade, the Jizhong depression has been one of the most extensively explored areas in the North China basin. The Jizhong is a half-graben structure bounded by the Taihang Shan highland on the west, the Cangxian uplifted block on the east, the Yan Shan fold belt on the north, and uplifted fault blocks on the south (figs. 2, 7). The 
depression is approximately $25,000 \mathrm{~km}^{2}$ in area (Zha, 1984 , p. 983). The sedimentary cover of the Jizhong depression ranges in thickness from 2,000 to about $13,000 \mathrm{~m}$, of which about $7,000 \mathrm{~m}$ are of Tertiary strata. In the Tertiary sequence, Paleogene beds are about 4,500 m thick (pl. 2). $\mathrm{Li}$ and others $(1984$, p. 9) reported that, in the northern part of the depression, the Tertiary sequence has a maximum thickness of about $10,000 \mathrm{~m}$.

\section{Source Rocks}

In the Jizhong depression, principal petroleum source rocks are confined to continental saline lake deposits of mudstone, shale, and oil shale of the Paleogene Shahejie and Dongying Formations. Secondary source rocks in the basin consist of the continental Jurassic and Cretaceous coal-bearing series, the continental and marine Carboniferous and Permian coal-bearing series, and the marine lower Paleozoic and Middle and Late Proterozoic carbonate rocks, shale, and mudstone (pl. 2; Zha, 1984).

Throughout the North China basin, the Shahejie Formation contains strata that are the most favorable for oil and gas generation. In the Jizhong, the third member of the Shahejie contains the highest quality source rocks. The second best source rocks are from the other three members of the Shahejie and the second member of the Dongying Formation. The source beds are generally concentrated in the Bieguzhuang-Guxinzhuang area of the northern part of the Jizhong depression, the Renqiu area of the central part of the depression, and the Jingqiu area of the southern part of the depression (fig. 7). Zha (1984, p. 988) estimated that, in the central Jizhong, the maximum thickness of the Paleogene source beds is greater than $1,000 \mathrm{~m}$. Generally, in the Jizhong, the thickest and richest source beds were deposited along the downthrown side of growth faults, where conditions are favorable for subsequent oil and gas generation and preservation.

In the Chaheji and the Jingqiu oil fields of the Jizhong depression (fig. 7), the organic carbon content of the source rocks ranges from 0.41 to about 1 weight percent, and the petroleum genetic potential (Tissot and Welte, 1984, p. 509-513) ranges from 250 to $689 \mathrm{ppm}$ (parts per million) (fig. 7, Wu and Liang, 1984, p. 11, 15-16). The minimum depth of oil and gas maturation in this depression is 2,800 m. Peak generation was attained between 2,800 and 4,600 $\mathrm{m}$, corresponding respectively to vitrinite reflectance values of 0.5 and 1.1 percent (fig. 8; $\mathrm{Li}$ and others, 1984; Wu and Liang, 1984). Li and others (1984) indicated that the temperatures required to generate oil and gas from source rocks range from 97 to $150{ }^{\circ} \mathrm{C}$. Methane gas was produced at a depth greater than $4,600 \mathrm{~m}$ and a corresponding temperature greater than $150{ }^{\circ} \mathrm{C}$. Humic kerogen (type III) is dominant in the northern part of the depression, whereas humic-sapropelic kerogen (type II) is dominant in the central and southern parts of the depression (Zha, 1984, p. 988).

Additional source rocks in the Jizhong depression include a 580-m-thick Lower Cretaceous lacustrine sequence consisting of fossiliferous gray to grayish-green mudstone intercalated with thin-bedded carbonate rocks located in the vicinity of Shijiazhuang, which is southwest of the Jizhong depression (fig. 2; Hu and others, 1982, p. $5)$. The organic carbon content of this unit ranges from 0.80 to 1.12 percent. The extractable organic matter (G.E. Claypool, oral commun., 1987) ranges from 650 to 1,500 ppm, whereas the pyrolyzed petroleum genetic potential ranges from 550 to $940 \mathrm{ppm}$.

Potential petroleum source rocks in the Jizhong depression include grayish-green black mudstone of the Carboniferous to Permian coal-bearing series, carbonate rocks of Cambrian and Ordovician age, and the black shale, marl, and limestone of Middle and Late Proterozoic Jixian and Qingbaikou age. Subsurface samples from the central and southern Jizhong provide basic data on the organic carbon content and extractable organic matter of Middle and Late Proterozoic source rocks (Hao and Zhang, 1984, p. 9). In the central Jizhong, the organic carbon content of shale and marl ranges from 0.36 to 1.12 percent, and the extractable organic matter ranges from 90 to $289 \mathrm{ppm}$. The organic carbon content of the limestone in this area ranges from 0.3 to 0.44 percent, and the extractable organic matter ranges from 83 to $347 \mathrm{ppm}$. In the southern Jizhong, the organic carbon content of shale ranges from 0.15 to 0.55 percent, and the extractable organic matter ranges from 57 to $180 \mathrm{ppm}$. Limestone from one locality yielded an organic carbon content of 0.15 percent and an extractable organic matter of 73 ppm. Hao and Zhang (1984, p. 7-8) considered that these source rocks in the Jizhong had reached a wet-gas stage of maturation. However, several oil-bearing Middle and Late Proterozoic sandstone units have been encountered in some exploratory wells, and 38 oil shows have been reported in the Yan Shan fold belt north of the North China basin (Hao and Zhang, 1984, p. 8). Zha (1984, p. 992) believes that oil and gas pools in the Middle and Late Proterozoic, Cambrian, and Ordovician carbonate reservoirs in the Jizhong were possibly derived from source rocks of their respective ages.

On the basis of sterane and terpane stereoisomers, Zhang and others (1983, p. 89-99) considered that the crude oil in the Middle and Late Proterozoic carbonate rock reservoirs of the Renqiu oil field came from the first and third members of the Shahejie Formation, whereas the crude oil in the Ordovician carbonate rock reservoirs came from the Kongdian Formation.

\section{Reservoir Rocks}

In the Jizhong depression, potential petroleum reservoir rocks are the sandstone, conglomerate, and carbonate rocks of the Middle and Late Proterozoic, Paleozoic, 


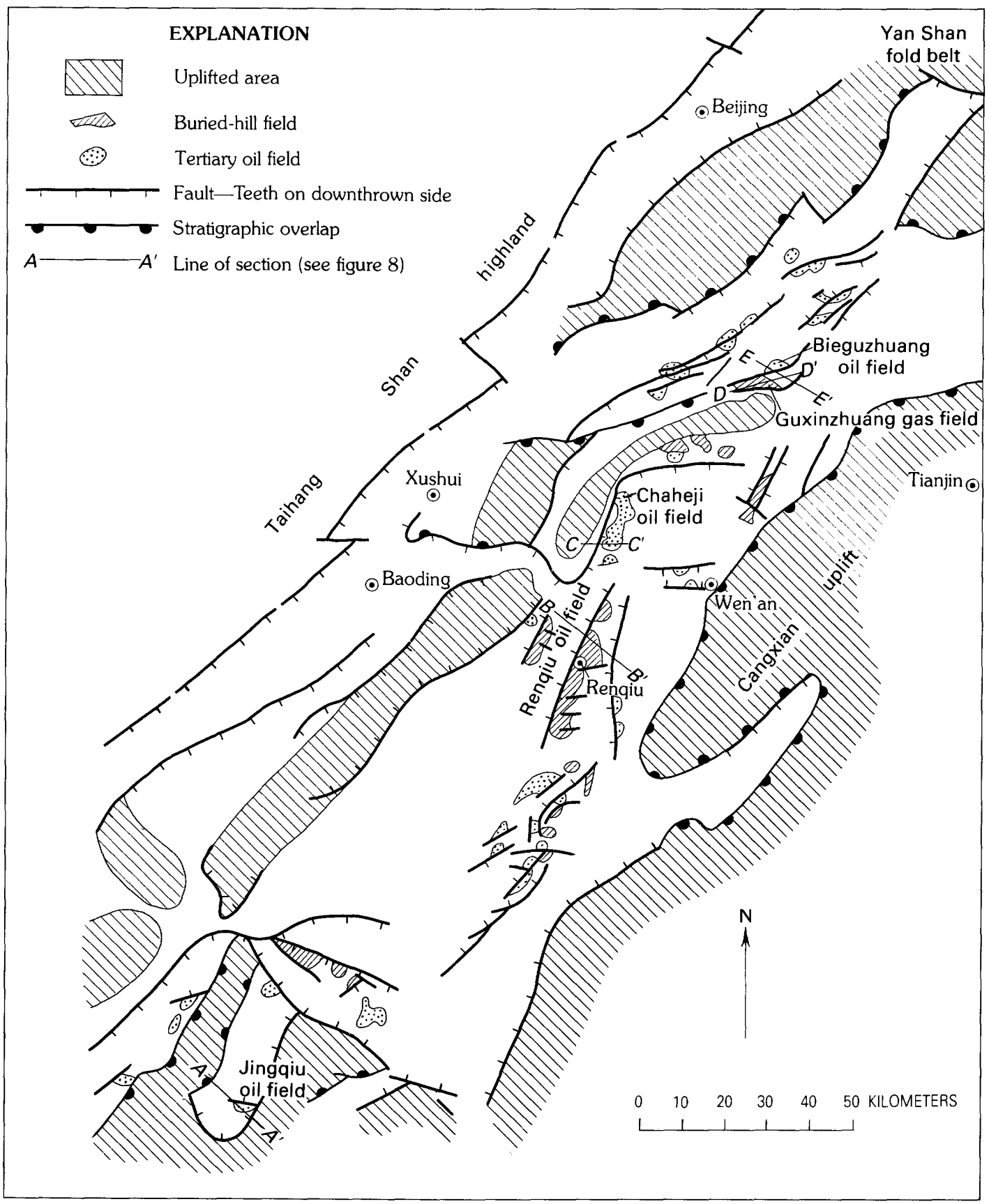

Figure 7. Principal structural units and oil and gas fields in the Jizhong depression, North China basin (modified from Wu and Liang, 1984).

Jurassic-Cretaceous, and Tertiary sedimentary sequences. Wu and Liang (1984) reported that 18 oil fields have been discovered in the depression. Of these fields, three have been studied by Wu and Liang (1984), and two have been described by Petroconsultants Ltd. (1983) (table 2). The principal reservoir rocks in these fields are sandstone, conglomerate, dolomite, limestone, and quartzite of Middle
Proterozoic (Changcheng and Jixian), Cambrian, Ordovician, and Tertiary age (table 2 ).

The oldest reservoir rock in the Jizhong is a quartzite of Changcheng age (table 2; Petroconsultants Ltd., 1982). This rock is generally fractured, has poor porosity and permeability, and produces 210 to $430 \mathrm{bbl} / \mathrm{d}$ (barrels per day) of oil. Dolomite of Jixian age is the principal oil- 


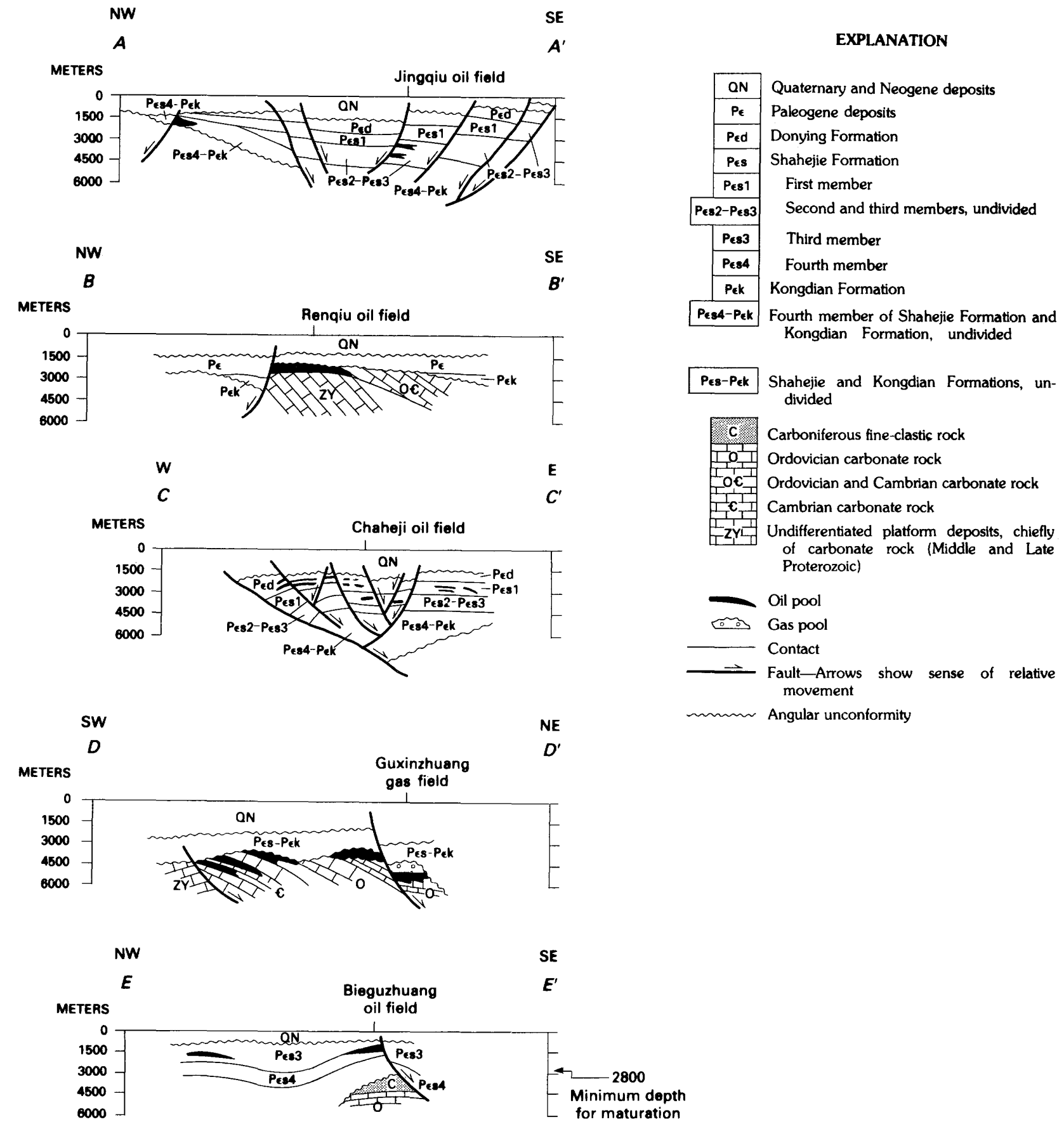

Figure 8. Schematic cross sections of principal oil and gas fields in the Jizhong depression, North China basin (modified from Petroconsultants Ltd., 1982; Wu and Liang, 1984). Locations of sections shown on figure 7.

bearing reservoir rock in the Renqiu buried-hill oil field (approximate lat $38^{\circ} 45^{\prime} \mathrm{N}$., long $116^{\circ} 00^{\prime}$ E.; figs. 7, 8). This reservoir contains a network of fractures that have been enlarged by dissolution (Yang and $\mathrm{Li}, 1980$, p. 57-64; Bai and Wang, 1984, p. 43-55; Fei and Wang, 1984) and has good porosity and permeability (table 2; Petroconsultants Ltd., 1982). The average daily output from the Jixian dolomite ranges from 1,400 to $7,150 \mathrm{bbl}$ (barrels) of oil per well. Fei and Wang (1984) mentioned that the reservoir consists of northeast-, north-northeast-, and northwesttrending fractures, which, due to enlargement by dissolution, provide good channels for oil migration and accumulation. Karstification of the Jixian dolomite occurred between the late stage of the Late Cretaceous Yanshanian orogeny and Eocene sedimentation. During the initial phase of Cenozoic extensional tectonics, the pre-Tertiary strata in 
Table 2. Physical properties of the reservoirs, types of traps, and cap rocks in the prominent oil and gas fields of the Jizhong Depression, North China basin

[ See figure 8 for map symbols and cross sections of the Jizhong; Pek, Paleogene Kongdian Formation; Pes4, Pes3, Pes2, and Pes1: fourth, third, second, and first members of the Paleogene Shahejie Formation; P $\epsilon$, Paleogene Shahejie Formation; P $\epsilon \mathrm{d} 2$, second member of the Paleogene Dongying Formation; - , no data]

\begin{tabular}{|c|c|c|c|c|c|c|c|}
\hline \multirow{2}{*}{ Oil field } & \multirow{2}{*}{$\begin{array}{l}\text { Reservoir } \\
\text { rock } \\
\text { and age }\end{array}$} & \multicolumn{3}{|c|}{ Physical properties } & \multirow{2}{*}{ Trap type } & \multirow{2}{*}{$\begin{array}{l}\text { Cap rock } \\
\text { and age }\end{array}$} & \multirow{2}{*}{ Remarks } \\
\hline & & $\begin{array}{l}\text { Porosity } \\
\text { (percent) }\end{array}$ & $\begin{array}{l}\text { Permeability } \\
\text { (md) }\end{array}$ & Sorting & & & \\
\hline Bieguzhuang & $\begin{array}{l}\text { Barrier-bar quartz- } \\
\text { ose sandstone } \\
\text { (P€s4), Eocene } \\
\text { and Oligocene. }\end{array}$ & 28 & 158 & $\begin{array}{l}\text { Good to } \\
\text { fair. }\end{array}$ & $\begin{array}{l}\text { Structural, host block in } \\
\text { a faulted anticline; } \\
\text { northeast and east- } \\
\text { west normal fault sys- } \\
\text { tem having } 500-600 \\
\text { m displacement and a } \\
\text { closure of } 600 \mathrm{~m} \text { in } \\
\text { an area of } 7 \mathrm{~km}^{2} \text {. }\end{array}$ & $\begin{array}{l}\text { Mudstone (Pes3), } \\
\text { Oligocene: } \\
50-240 \mathrm{~m} \\
\text { thick. }\end{array}$ & $\begin{array}{l}\text { Oil and gas pools at depth, } \\
1,200-1,800 \mathrm{~m} \text {; sealed by } \\
\text { P } \in 3 \text { mudstone; pay zone } \\
50-60 \mathrm{~m} \text { thick and formed } \\
\text { in late } P \in 2 \text {. Source rock, } \\
\text { PE4 dark shale (Wu and } \\
\text { Liang, 1984, p. 4-9; Li } \\
\text { and others, 1984). }\end{array}$ \\
\hline Chaheji & $\begin{array}{c}\text { Channel sand- } \\
\text { stone (P€s1 } \\
\text { and } P \in d 3), \\
\text { Oligocene. }\end{array}$ & $22-28$ & $100-500$ & Good & $\begin{array}{l}\text { Lithologically pinching } \\
\text { out and anticline bro- } \\
\text { ken by north-northeast } \\
\text { and east-west normal } \\
\text { fault system having } \\
100-300 \mathrm{~m} \text { displace- } \\
\text { ment and a closure of } \\
800 \mathrm{~m} \text { in an area of } \\
80 \mathrm{~km}^{2} \text {. }\end{array}$ & $\begin{array}{c}\text { Mudstone }(\mathrm{P} \in \mathrm{d} 2) \\
\text { Oligocene. }\end{array}$ & $\begin{array}{l}\text { Pay zone generally } 10-20 \mathrm{~m} \\
\text { thick. Normal faults act as } \\
\text { oil and gas supply chan- } \\
\text { nel. Wells near the faults, } \\
\text { have lighter oil and } \\
\text { heavier gas ( } 700 \mathrm{bbl} / \mathrm{d} \text { of } \\
\text { oil and } 36 \text { million } \mathrm{ft}^{3} / \mathrm{d} \text { of } \\
\text { gas) and formed in late } \\
\text { Oligocene to early } \\
\text { Miocene. Pes3, source } \\
\text { rock (Wu and Liang, } \\
\text { 1984, p. 11-14). }\end{array}$ \\
\hline Jingqiu & $\begin{array}{l}\text { Delta front quartz- } \\
\text { ose sandstone } \\
\text { (Pєs2 and } \\
\text { Pes3), Oli- } \\
\text { gocene. }\end{array}$ & 16 & 425 & Fair & $\begin{array}{l}\text { Faulted nose structure } \\
\text { cut by east-west nor- } \\
\text { mal fault system that } \\
\text { has a closure of about } \\
150 \mathrm{~m} \text { in an area of } \\
13.5 \mathrm{~km}^{2} \text {. }\end{array}$ & $\begin{array}{l}\text { Anhydrite rock } \\
\text { salt and mud- } \\
\text { stone (Pєs2), } \\
\text { Oligocene; } \\
\text { 100-150 m } \\
\text { thick. }\end{array}$ & $\begin{array}{l}\text { Oil pool near the center of } \\
\text { source area. The source } \\
\text { rocks, dark mudstone in } \\
\text { P } \epsilon \text { s, contain organic car- } \\
\text { bon, } 0.41 \text { to } 0.71 \text { percent, } \\
\text { and average hydrocarbon } \\
\text { content is } 250 \text { ppm. Pool } \\
\text { formed in Miocene Guan- } \\
\text { tao (Wu and Liang, 1984, } \\
\text { p. 15-17). }\end{array}$ \\
\hline Renqiu & $\begin{array}{l}\text { Dolomite and } \\
\text { limestone of } \\
\text { Middle and } \\
\text { Late Protero- } \\
\text { zoic, Cam- } \\
\text { brian, and } \\
\text { Ordovician } \\
\text { age, as well as } \\
\text { Middle Prot- } \\
\text { erozoic } \\
\text { Changcheng } \\
\text { quartzite. }\end{array}$ & $\begin{array}{l}\text { Good secondary } \\
\text { vugs, caverns, } \\
\text { and fractures } \\
\text { in carbonate } \\
\text { rocks. Poor } \\
\text { fractures in } \\
\text { quartzite. }\end{array}$ & $\begin{array}{l}\text { Good in carbon- } \\
\text { ate rocks and } \\
\text { poor in quartz- } \\
\text { ite. }\end{array}$ & - & $\begin{array}{l}\text { Structural-stratigraphic. } \\
\text { buried hills having } \\
\text { unconformity and sub- } \\
\text { sequent folding and } \\
\text { faulting providing the } \\
\text { entrapment of about } \\
200 \mathrm{~km}^{2} \text {. }\end{array}$ & $\begin{array}{l}\text { Mudstone and } \\
\text { anhydrite, } \\
\text { Eocene to } \\
\text { Oligocene. }\end{array}$ & $\begin{array}{l}\text { Discovery in } 1975 \text {. Third } \\
\text { most productive field in } \\
\text { China. Depth to top pay, } \\
2,740 \mathrm{~m} \text {. Reservoir- } \\
\text { bearing interval up to } 850 \\
\text { or } 2,790 \mathrm{~m} \text {. Ultimate } \\
\text { recoverable oil, } 2 \text { billion } \\
\text { bbl (Petroconsultants Ltd., } \\
\text { 1982). }\end{array}$ \\
\hline Guxinzhuang & $\begin{array}{l}\text { Limestone, frac- } \\
\text { tured and } \\
\text { weathered, } \\
\text { Ordovician. }\end{array}$ & $\begin{array}{l}\text { Vugs and } \\
\text { fractures. }\end{array}$ & Good & - & $\begin{array}{l}\text { Structural-stratigraphic, } \\
\text { buried hills and fault } \\
\text { system. }\end{array}$ & $\begin{array}{l}\text { Mudstone } \\
(P \in k)(P \in s), \\
\text { Eocene to } \\
\text { Oligocene. }\end{array}$ & $\begin{array}{l}\text { Gas field. Depth to top pay, } \\
3,389 \mathrm{~m} \text {. Gross thickness } \\
\text { of reservoir interval, } 190 \\
\mathrm{~m} \text {. Initial test flow rate of } \\
\text { gas for a single well may } \\
\text { reach } 35 \text { million } \mathrm{ft}^{3} / \mathrm{d} \text { con- } \\
\text { taining a small amount of } \\
\text { crude oil (Petroconsultants } \\
\text { Ltd., 1982). }\end{array}$ \\
\hline
\end{tabular}


the Jizhong were differentially uplifted, downwarped, and then buried by Paleogene source rocks. Fei and Wang (1984) further stated that, as growth faults in Middle and Late Proterozoic carbonate rocks developed, individual fault blocks in the depression were raised $400 \mathrm{~m}$ in the Eocene and $1,300 \mathrm{~m}$ in the Oligocene. The Jixian dolomite reservoir of the Renqiu field has $800 \mathrm{~m}$ of structural closure (fig. 8).

Cambrian and Ordovician limestone and dolomite in the Jizhong depression are good reservoirs because these rocks have fairly well developed fractures and solution features and local fault breccias. The Renqiu oil field consists of four satellite buried-hill accumulations named the Baxian, Hejian, Yanling, and Yongqing fields (table 2; Petroconsultants Ltd., 1982). The Cambrian and Ordovician carbonate rocks in these buried-hill oil fields have good permeability because of secondary vugs, caverns, and fractures. Petroconsultants Ltd. (1982) estimated that the ultimate recoverable reserves of the Renqiu oil field are 2 billion bbl of oil. Cambrian and Ordovician limestone is probably the major reservoir in the Guxinzhuang gas field (approximate lat $39^{\circ} 10^{\prime} \mathrm{N}$., long $116^{\circ} 30^{\prime}$ E.), where an initial test flow of about 35 million $\mathrm{ft}^{3} / \mathrm{d}$ (cubic feet per day) of gas containing a small amount of oil was reported from the Ordovician fractured limestone (table 2, fig. 8; Petroconsultants Ltd., 1982).

Numerous reports have been published on the buriedhill oil and gas pools in the carbonate rocks of the North China basin (Li, 1980; Yan and others, 1980; Yan and Zhai, 1981; Fei and Wang, 1984; Zha, 1984). Yan and others (1980, p. 9) mentioned that special geologic conditions are required to create ideal buried-hill oil and gas pools. These pools must have formed in a depression containing extensive source beds that unconformably overlie the intensely weathered carbonate rock terrane. Also, the pools in the carbonate rocks must be in fault contact with the source beds, and this contact can then further act as a seal. The carbonate rocks must have vugs, fractures, and caverns and excellent cap rocks. Moreover, the carbonate rocks must have a relatively large closure in an area that has relatively stagnant hydrodynamic conditions. In the North China basin, the Renqiu buried-hill oil field has all of these specific geologic conditions. The Renqiu oil pool is located in a large fault block bounded on the west by a westerly dipping growth fault. The lower Paleozoic and Middle and Late Proterozoic carbonate reservoir rocks are tightly sealed by Paleogene shale, mudstone, and evaporite. The pools are massive and bedded and have an irregular wedge shape (Yan and others, 1980; Zha, 1984, p. 990). Zha (1984) further mentioned that, in the Jizhong depression, the buried-hill carbonate reservoirs are covered by coal beds of the Carboniferous, Permian, and Mesozoic sequences. Oil and gas in the Tertiary source rocks migrated along the unconformity into the buried-hill carbonate reservoirs and adjacent reservoir rocks. This mode of oil and gas migration reveals new areas for potential exploration of the buried-hill oil and gas pools (Zha, 1984, p. 989).

Reservoir rocks of Tertiary age in the Jizhong depression consist of quartzose sandstone and minor amounts of conglomerate. In the Bieguzhuang, Chaheji, and Jingqiu oil and gas fields, the sandstone has good to fair sorting, porosity ranging from 16 to 28 percent, and permeability ranging from 100 to $500 \mathrm{md}$ (a unit of permeability equal to 1/1,000 darcy) (figs. 7, 8, table 2; Wu and Liang, 1984).

\section{Traps and Seals}

Oil and gas in Tertiary sandstone reservoirs are trapped in structural anticlines, terraces, rolled-over anticlines, drape anticlines, and fault blocks. Accumulations also have resulted from the pinch out of sandstone units of fluvial-channel, barrier-bar, and turbidite origin and from sandstone units that have overlapped fault blocks. Marked changes in lithofacies are common because detrital sediments derived from surrounding highlands were deposited in a topographically closed depression. Therefore, the oiland gas-bearing sandstone reservoirs generally have a limited areal extent in the Jizhong depression, and current exploration has concentrated only on structural traps that contain buried-hill highs. Nevertheless, some commercial stratigraphically trapped oil and gas accumulations in sandstone reservoirs have been found in the Jizhong (fig. 8). Thick shale, mudstone, gypsum, and salt beds form extensive seals throughout the depression.

In the western part of the Jizhong depression, undiscovered oil accumulations may exist in Jurassic and Cretaceous sandstone beds, and, in the eastern part, undiscovered gas accumulations may exist in the Carboniferous to Permian and Jurassic to Cretaceous beds (Zha, 1984, p. 992).

\section{Dongpu-Kaifeng Depression}

The Dongpu-Kaifeng depression is a northeasterly trending graben system bordered on the west and east by horst blocks, on the south by the fault blocks of the Taikang upland, and on the north by a fault that separates the area from the Linqing depression (figs. 2, 9, pl. 1; Lin, 1982). The Dongpu-Kaifeng depression is located in the southern part of the North China basin, is about $7,000 \mathrm{~km}^{2}$ in area, and is crossed by the Huang He (fig. 2, pl. 1). The Tertiary sedimentary cover of the Dongpu-Kaifeng depression ranges in thickness from 2,270 to $5,600 \mathrm{~m}$, of which 4,500 $\mathrm{m}$ are Paleogene. The remaining sedimentary cover consists of $800 \mathrm{~m}$ of Jurassic and Cretaceous sequence, $800 \mathrm{~m}$ of Carboniferous and Permian coal-bearing sequence, $1,200 \mathrm{~m}$ of Cambrian and Ordovician carbonate sequence, and 0 to $800 \mathrm{~m}$ of Middle and Late Proterozoic sequence, of which the Sinian strata are missing (pl. 2). 


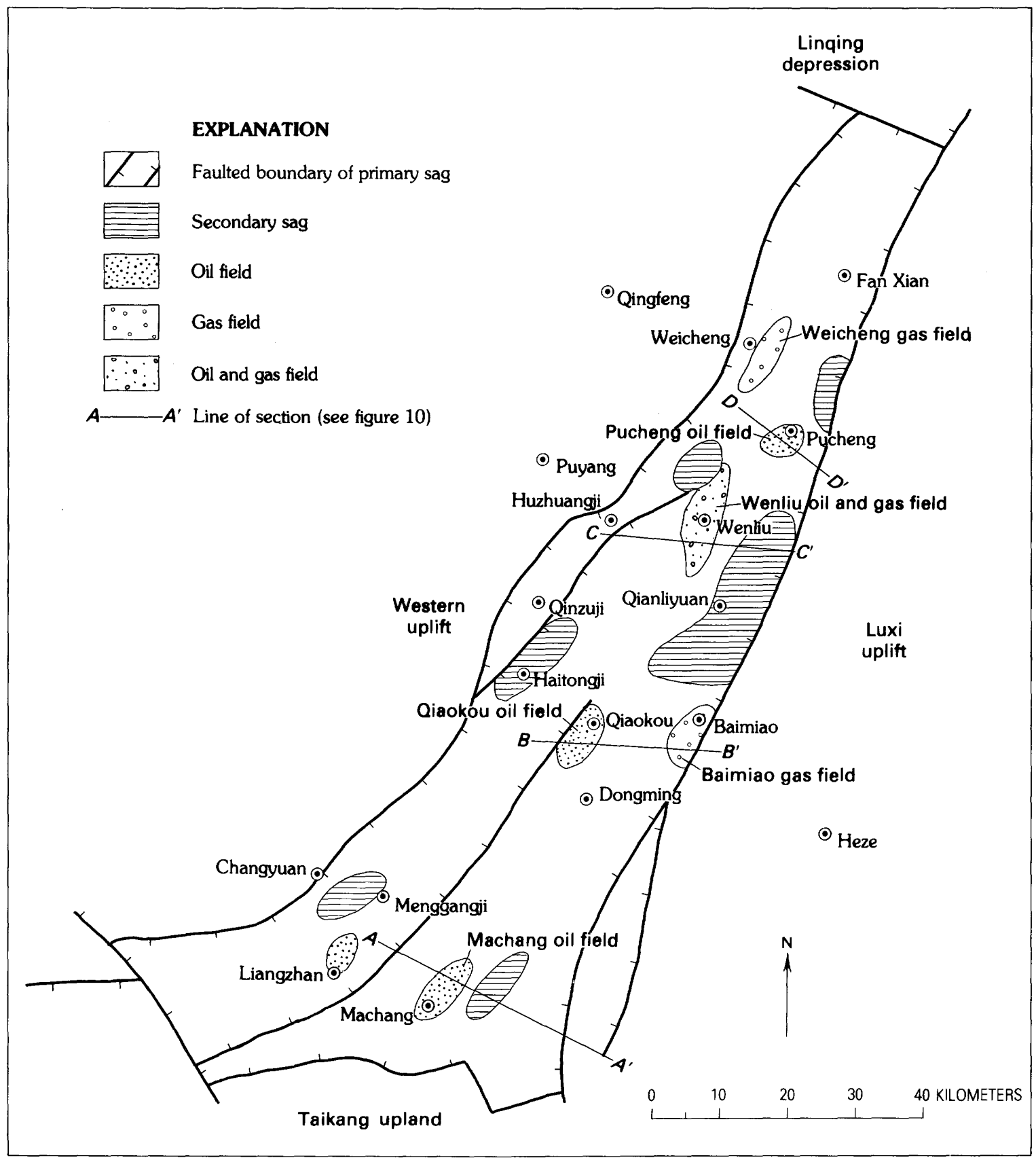

Figure 9. Principal structural units and oil and gas fields in the Dongpu-Kaifeng depression, North China basin (modified from Chen and others, 1984).

Source Rocks

The principal source rocks in the Dongpu-Kaifeng depression are the saline lacustrine deposits of mudstone, shale, and oil shale of the Paleogene Shahejie and Dongying Formations. Secondary source rocks consist of the continental and marine Carboniferous and Permian coal-bearing series and the marine Cambrian and Ordovician carbonate rocks, shale, and mudstone.

The major oil and gas generating strata are the grayish-green to gray mudstone of the third and first members of the Shahejie Formation (Chen and others, 1984 , p. 379). Source beds are as much as $1,000 \mathrm{~m}$ in thickness in the northern, eastern, and central parts of the depression (fig. 10). The dominant kerogen variety is mixed humic-sapropelic (type II). The peak generation of oil and gas was at depths between 2,400 and 4,100 m; these depths correspond, respectively, to temperatures of 90 and $145^{\circ} \mathrm{C}$ (fig. 10; Chen and others, 1984, p. 379).

The Carboniferous to Permian coal series is widely distributed in the Dongpu-Kaifeng depression, and, during 


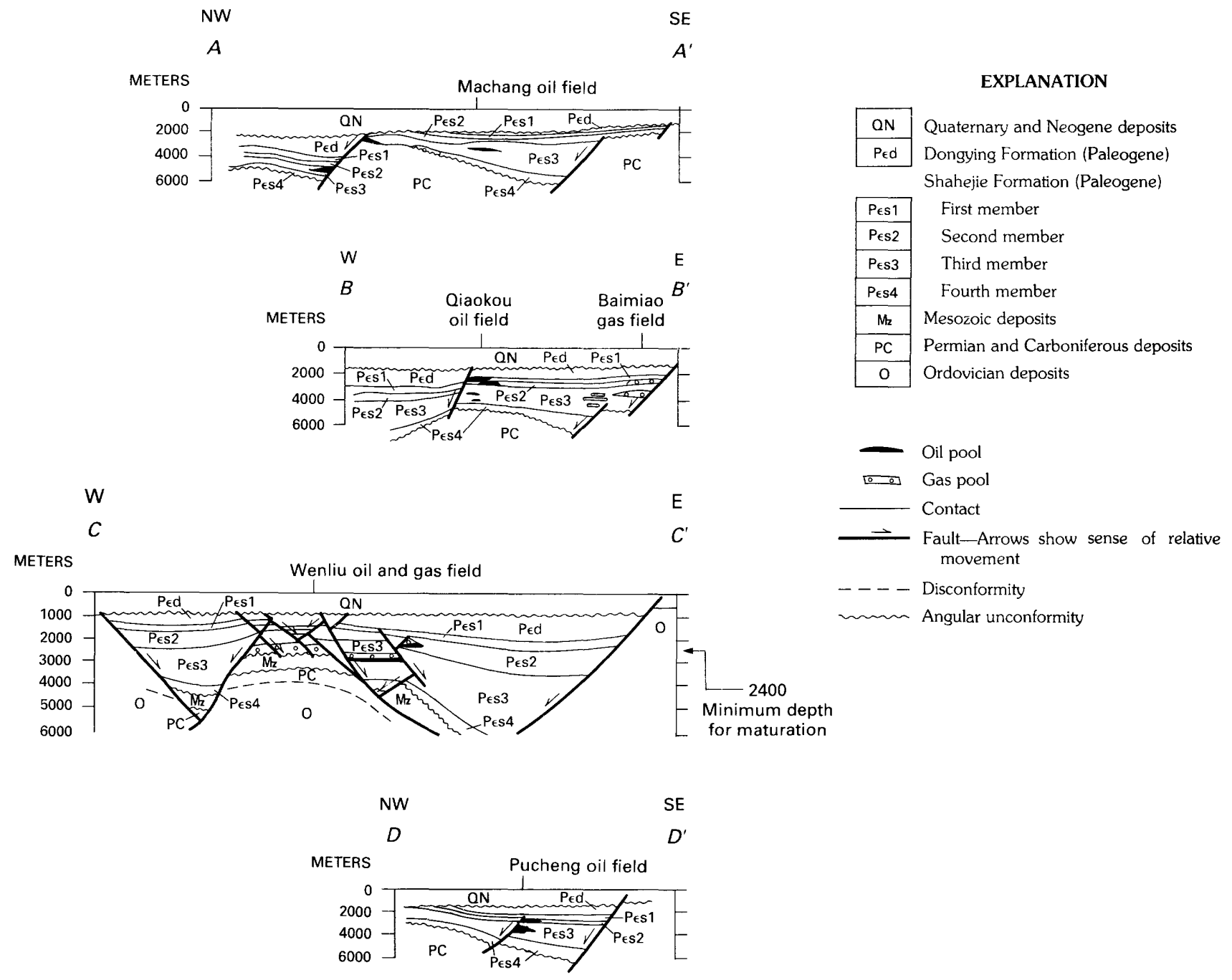

Figure 10. Schematic cross sections of principal oil and gas fields in the Dongpu-Kaifeng depression, North China basin (modified from Chen and others, 1984; Zhu and Xu, 1984). Locations of sections shown on figure 9.

the late Paleogene, a substantial amount of gas migrated into this depression. Generally, the thickness of the coal series in the Dongpu-Kaifeng averages about $250 \mathrm{~m}$, and the rank ranges from a high-volatile bituminous coal to a meta-anthracite coal (Cai, 1983). In the northern part of the depression, the average total thickness of Carboniferous to Permian coal beds is $12 \mathrm{~m}$, whereas, in the southern part of the depression, the average total thickness of the coal beds is $7 \mathrm{~m}$ (Zhou and others, 1985, table 2). The total organic carbon content in the coal series averages between 1.28 and 2.81 weight percent (Cai, 1983, table 1). At the Wenliu oil and gas field (figs. 9, 10), Carboniferous to Permian coking coal beds are found below $4,427 \mathrm{~m}$ at a temperature of 152 ${ }^{\circ} \mathrm{C}$ and a vitrinite reflectance of 1.5 percent (Cai, 1983). $\mathrm{Zhu}$ and $\mathrm{Xu}$ (1984) stated that gas generated from Carboniferous to Permian coal beds has a higher methane content (greater than 95 percent), higher $\delta C^{13}$ values $(-27.1$ to $-30.3 \%$, per mil, in parts per thousand), and larger
${ }^{40} \mathrm{Ar} /{ }^{36} \mathrm{Ar}$ ratios $(958$ to 1,396$)$ than gas generated from the Tertiary source-rock sequences. Therefore, the upper Paleozoic gas source might have driven out the oil produced from the Tertiary source rocks.

The organic content of the Cambrian and Ordovician carbonate rocks, shale, and mudstone in the DongpuKaifeng depression is generally unknown. However, Fu and Jia (1984) stated that the minimum total organic carbon values in the Cambrian and Ordovician carbonate source rocks of the North China basin range from 0.08 to 0.2 weight percent.

\section{Reservoir Rocks}

Tertiary (Paleogene) sandstone and conglomeratic sandstone are the principal reservoir rocks in the DongpuKaifeng depression. At present, the major fields are the Pucheng and Wenliu oil and gas fields (figs. 9, 10). Petroconsultants Ltd. $(1982,1983)$ listed the Pucheng field 


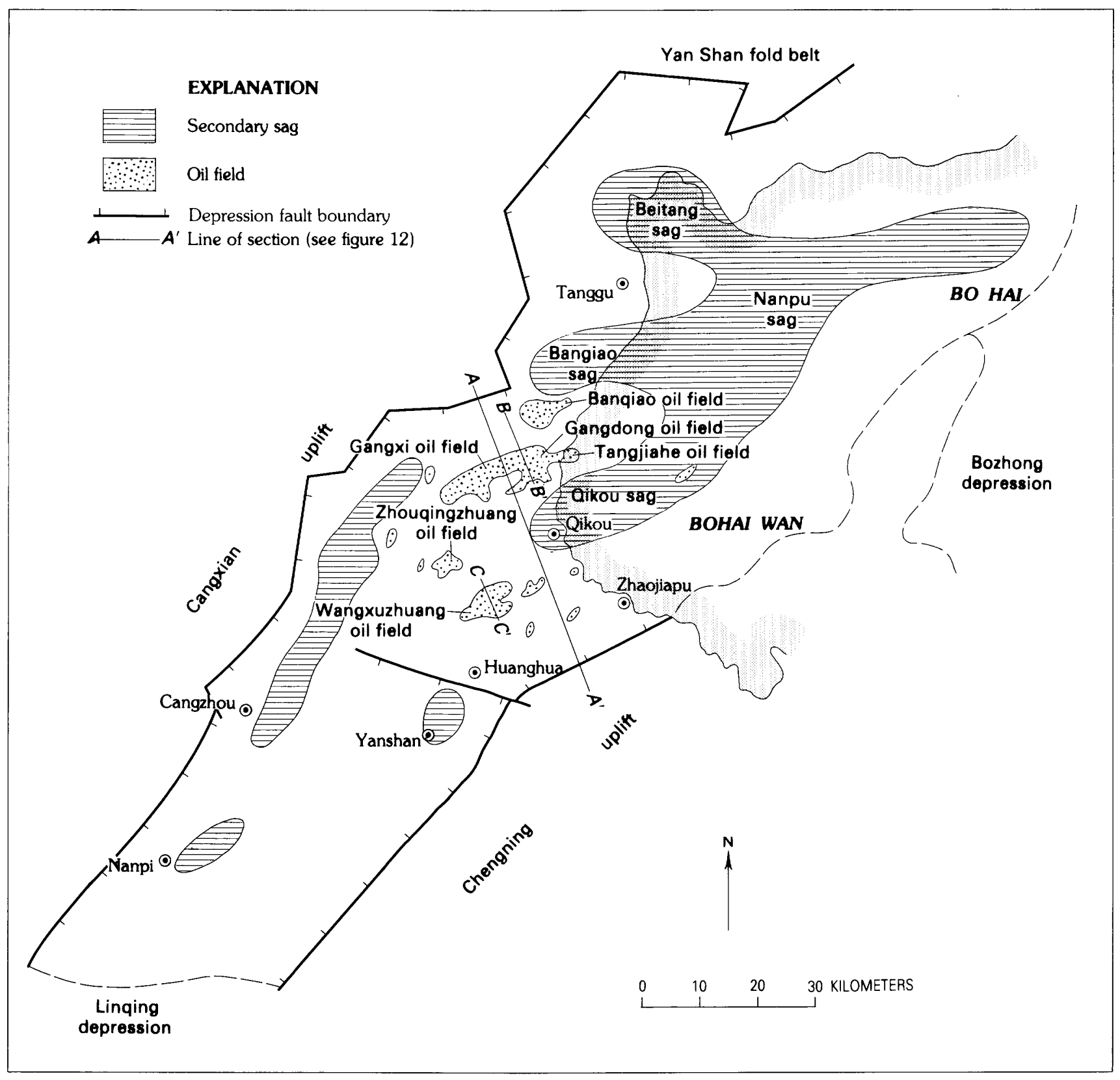

Figure 11. Principal structural units and oil fields in the Huanghua depression, North China basin (modified from Zhang and Jian, 1981; Wang and others, 1983).

as the "Dongpu" oil field and estimated an annual production of 13.87 million bbl from Paleogene sandstone in a faulted anticline. The main gas pools are located in the Wenliu field. Zhu and Xu (1984) and Chen, Zhou, Qiu, and Guo (1984), however, provide information on additional oil and gas deposits in the Pucheng, Wenliu, Weicheng, Qiaokou, Baimiao, and Machang areas and the area between the cities of Huzhuangji and Qinzuji along the west border of the depression (fig. 9).

In the Dongpu-Kaifeng depression, gas deposits generally are the principal petroleum resource (fig. 9). On the basis of geochemical data, Zhu and Xu (1984) have recognized three types of gas deposits in the depression: (1) gas generated from the Carboniferous to Permian coal beds, such as that at the Wenliu field, is characterized by a methane content of more than 95 percent and a low wet-gas content; (2) gas generated from Tertiary oil, such as that in the Pucheng field, is characterized by a methane content below 95 percent, lower $\delta \mathrm{C}^{13}$ values ( -38.62 to $-45.4 \%$ oo) and smaller ${ }^{40} \mathrm{Ar} /{ }^{36} \mathrm{Ar}$ ratios (343 to 626 ) than that from the Carboniferous to Permian coal source; and (3) gas generated from Carboniferous and Permian coal and Tertiary oil, such 


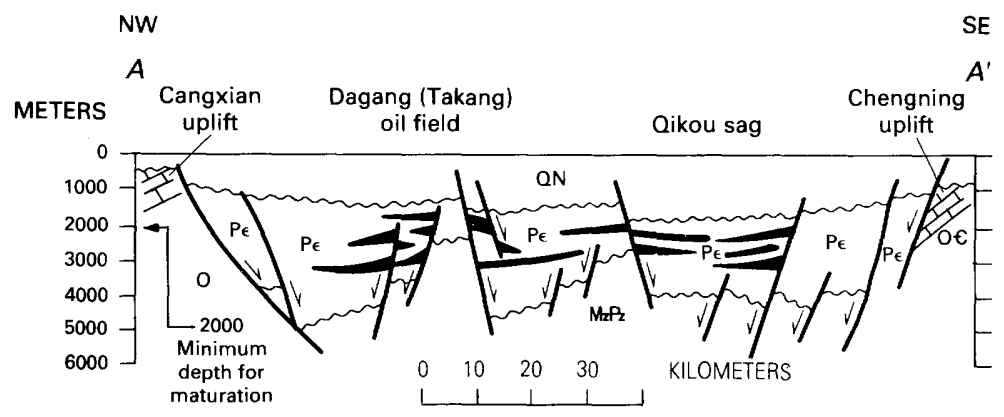

EXPLANATION

QN Quaternary and Neogene deposits-N Minghuazhen and Guantao Formations, undifferentiated

$\mathrm{Nm}$ Minghuazhen Formation (Neogene)

$\mathrm{Ng}$ Guantao Formation (Neogene)

Ped Dongying Formation (Paleogene)

P€S Shahejie Formation (Paleogene)

Dongying, Shahejie, and Kongdian

Formations, undifferentiated (Paleogene)

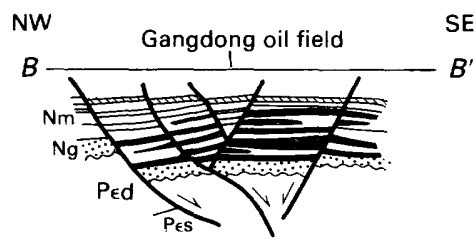

MzP Mesozoic and Paleozoic deposits

Ordovician carbonate rocks

Ordovician and Cambrian carbonate rocks

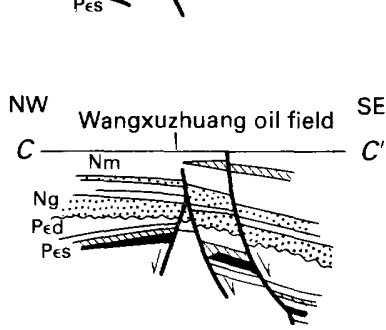

Evaporite

Conglomeratic sandstone

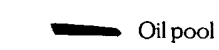

Contact

- Fault-Arrows show relative sense of movement

Angular unconformity

Figure 12. Schematic cross sections of principal oil fields in the Huanghua depression, North China basin (modified from Liu and others, 1981). Locations of sections shown on figure 11.

as that in the Weicheng field, is called a mixed-type gas and is characterized by methane contents from 31 to 69 percent, $\delta \mathrm{C}^{13}$ values ranging from 32.1 to $35.0 \mathrm{o} / \mathrm{oo}$, and ${ }^{40} \mathrm{Ar} /{ }^{36} \mathrm{Ar}$ ratios ranging from 780 to 868 .

\section{Traps and Seals}

The Wenliu gas reservoir is located in sandstone and siltstone of the undifferentiated third and fourth members of the Shahejie Formation (fig. 10, pl. 2). The reservoir is completely sealed by a 600 - to 800 -m-thick sequence of rock salt and gypsum beds (fig. 10) in the lower part of the third member of the Shahejie Formation ( $\mathrm{Zhu}$ and $\mathrm{Xu}$, 1984, p. 9). The trap is a horst block.

In the Pucheng oil and gas field, gas is trapped in a fault block against sealed salt beds in the upper part of the third member of the Shahejie (fig. 10). Gas in the Weicheng field was generated from the third and fourth members of the Shahejie Formation and from Carboniferous and Permian coal beds. This gas was trapped in a fashion similar to that of the gas in the Pucheng field. Fault traps and stratigraphic traps are present in the Baimiao, Qiaokou, and Machang fields. Detailed exploration is needed in the southern part of the depression where gas potential is high.

\section{Huanghua Depression}

The Huanghua depression is a half-graben structure (figs. 11, 12), located in the central part of the North China basin. The depression is bounded by the Linqing depression on the south, the Yan Shan fold belt on the north, the Cangxian uplift on the west, and the Chengning uplift and the Bozhong depression on the east (figs. 2, 11, 12). The Huanghua depression is about $250 \mathrm{~km}$ in length, 50 to 100 $\mathrm{km}$ in width, and $17,000 \mathrm{~km}^{2}$ in area. Four large oilproducing sags in the depression are the Qikou, Banqiao, Beitang, and Nanpu, of which the Qikou and Banqiao contain the thickest source beds. The Dagang oil field (approximate lat $38^{\circ} 20^{\prime} \mathrm{N}$., long $117^{\circ} 50^{\prime}$ E.) is situated between the Banqiao sag on the northwest and the Qikou sag on the southeast. The so-called "Dagang field" is a collective name for the Banqiao oil field in the north and the Tangjiahe, Gangdong, and Gangxi oil fields in the south (fig. 11). The maximum thickness of the sedimentary cover in the Huanghua depression is about $12,000 \mathrm{~m}$, of which $8,390 \mathrm{~m}$ are Tertiary. The maximum thickness of the Paleogene sequence is $5,490 \mathrm{~m}$ (pl. 2). 
Source Rocks

In the Huanghua depression, principal source rocks are confined to the continental saline lake deposits of mudstone, shale, oil shale, and marl of the Paleogene Shahejie and Dongying Formations. Additional source rocks consist of coal beds in Carboniferous and Permian sequences and marine carbonate rocks, shale, and mudstone in the Middle to Late Proterozoic and Cambrian to Ordovician sequences (pl. 2).

The third, second, and first members of the Shahejie Formation, followed by the lower part of the Dongying Formation, contain the principal oil and gas generating strata of the Huanghua depression. These source rocks are concentrated in the central part of the depression (Liang and others, 1981, p. 75 ) and are $1,260 \mathrm{~m}$ thick in the Banqiao sag and 1,560 m thick in the Qikou sag (fig. 11). The source rocks contain abundant diatoms, pollen, spores, ostracodes, and gastropods. The organic carbon content ranges from 0.52 to 2.76 weight percent and averages 1.26 percent. The extractable organic matter averages 0.13 weight percent. The primary pyrite content in the source rocks is generally high, as indicated by the reduction coefficient $(\mathrm{K})$ from 0.2 to 0.37 and the sulfur content from 0.13 to 0.51 percent (Liang and others, 1981, p. 75). These data indicate that the Oligocene lake deposits of the Shahejie Formation were fresh to semialkaline, ranged from moderate to deep, and contained sediments that were deposited in a weakly reducing environment.

The evolution of organic matter in the Paleogene source rocks of the Huanghua depression was studied by Wang and others (1980), Liang and others (1981), and Liang (1985). Liang (1985) stated that oil and gas generation occurred in the Huanghua between depths of 2,000 and $4,500 \mathrm{~m}$; these depths correspond, respectively, to temperatures of 85.5 and $171{ }^{\circ} \mathrm{C}$ (fig. 12). The hydrocarbons in this depression have the following characteristics, as depth increases: (1) Immature heavy oil containing biogenic methane occurs at depths between about 2,000 and 2,400 $\mathrm{m}$; these depths correspond to temperatures between 85.5 and $97.5^{\circ} \mathrm{C}$. (2) Three mature oil zones associated with gas represent an immature heavy oil, a moderately mature medium oil, and a mature light oil and occur between depths of 2,400 and 4,000 $\mathrm{m}$; these depths correspond to temperatures between 97.5 and $154{ }^{\circ} \mathrm{C}$. (3) Highly mature condensate and wet gas occur between depths of 4,000 and $4,500 \mathrm{~m}$; these depths correspond to temperatures between 154 and $171{ }^{\circ} \mathrm{C}$. (4) Overmature dry methane gas occurs below a depth of $4,500 \mathrm{~m}$ and has a corresponding vitrinite reflectance of 2.0 percent (Liang, 1985, fig. 1).

Fu and Jia (1984, fig. 5, table 3) indicated that, for many parts of the Huanghua depression, Ordovician carbonate source rocks were subjected to temperatures from 430 to $440{ }^{\circ} \mathrm{C}$. The total organic carbon content of these rocks ranges between 0.1 and 0.2 weight percent. Informa- tion is not yet available for probable Middle to Late Proterozoic Jurassic to Cretaceous source rocks in the depression.

Correlation between oil extracts from source rocks and crude oil in the Huanghua depression was done by Liang and others (1981). Alkane properties suggest that oil and condensate in the Banqiao field were generated from the third member of the Shahejie Formation and that oil in the Tangjiahe field was generated from the second and third members of the Shahejie.

Reservoir Rocks

The principal producing reservoir rocks in the Huanghua depression are the sandstones of the Kongdian, Shahejie, Dongying, Guantao, and Minghuazhen Formations and the oolitic, bioclastic carbonate rocks of the Shahejie Formation (Zhang and Jian, 1981). Petroconsultants Ltd. (1977) mentioned that productivity in the Dagang field differs greatly from block to block, and even from well to well, probably because the reservoirs have intricate faulting and abrupt facies changes (figs. 11, 12). The beds of Paleogene oil-bearing reef limestone reservoirs are thick and commonly show abrupt facies changes in the direction of decreasing thickness. Oil-bearing sedimentary sequences occur mainly between depths of 1,500 and $3,000 \mathrm{~m}$. Petroconsultants Ltd. (1977) estimated that the annual production from the Dagang field in 1975 was 55 to 73 million bbl of oil.

The Dagang field was discovered in 1964. Since 1975, active exploration and drilling have continued throughout the Huanghua depression. The main Tertiary reservoirs occur in the delta front and channel sandstones that were deposited near a lacustrine shoreline. The Tertiary reef-limestone and dolomitic-limestone reservoirs have secondary vugs and fractures and contain local bioherms. Generally, these oil and gas deposits are trapped by faults, rollover anticlines, and stratigraphic pinch-outs that have mudstone seals (fig. 12).

\section{Jiyang Depression}

The Jiyang depression is located in the east-central part of the North China basin and is bounded by the Luxi uplift and the Tanlu deep fracture system on the south and east, the Bozhong depression on the north, the Chengning uplift on the west and northwest, and the Linqing depression on the southwest (figs. 2, 13). Geographically, the southern two-thirds of the Jiyang is made up of land surface, and the northern one-third is made up of shallow sea in the Bohai Wan (fig. 2, pl. 1).

The onshore portion of the Jiyang depression is the principal petroleum-producing area in the depression and consists of four major sags: Dongying, Zhanhua, Chezhen, and Huimin (fig. 13). The sags are separated from each 
other by uplifts (fig. 13). In 1962, the first petroleumproducing oil field found in the Zhanhua sag was called Shengli [Victory] field (figs. 13, 14). Since then, extensive onshore drilling in the depression has led to the discovery of numerous commercial oil and gas fields, which, at present, have been called throughout the published literature the "Shengli fields." Generally, the Jiyang depression is a half-graben structure made up of numerous normal fault blocks (fig. 3). The depression is about $17,000 \mathrm{~km}^{2}$ in area, of which $5,700 \mathrm{~km}^{2}$ are occupied by the Dongying sag (Tang, 1979, p. 14). The maximum thickness of the sedimentary cover in the Jiyang is about $8,230 \mathrm{~m}$, of which $7,270 \mathrm{~m}$ are Tertiary. The oil- and gas-bearing Paleogene sedimentary fill in the Jiyang ranges in depth from 2,900 to $5,750 \mathrm{~m}$ (pl. 2).

\section{Source Rocks}

In the Jiyang depression, the principal source rocks are confined to the fluviolacustrine fresh- to saline-water deposits of mudstone, shale, and oil shale of the Paleogene Kongdian and Shahejie Formations. The total thickness of the source rocks is approximately $1,000 \mathrm{~m}$ (Chen and Wang, 1980; Zhou, 1981). The third, second, and first members of the Shahejie Formation contain the major oiland gas-generating strata in this depression (Chen and Wang, 1980, p. 473; Zhou, 1981, p. 26-38). These source rocks have an oil and gas genetic potential of 400 to 1,000 $\mathrm{ppm}$; the extractable organic matter to total organic carbon ratio is greater than $100 \mathrm{mg} / \mathrm{g}$, and the petroleum genetic potential to total organic carbon ratio is greater than 30 $\mathrm{mg} / \mathrm{g}$ (Wang and others, 1983, p. 130). The dominant kerogen variety is humic-sapropelic (type II), as indicated by a hydrogen-carbon ratio of 1.10 to 1.35 and an oxygencarbon ratio of 0.06 to 0.18 . These values show that fewer aquatic organisms and more terrestrial plants are present in the source rocks (Wang and others, 1983, p. 131).

The average geothermal gradient in the Jiyang depression is $36{ }^{\circ} \mathrm{C} / \mathrm{km}$, and the average surface temperature is $14.2{ }^{\circ} \mathrm{C}$ (Chen and Wang, 1980, p. 39). On the basis of samples collected from the middle of the third member of the Shahejie Formation in the Dongying sag (Zhou, 1981, p. 39-47; Wang and others, 1983, p. 131-132), the mature stage for generation of oil and gas was determined to occur between the depths of 2,200 and $3,000 \mathrm{~m}$ and to have corresponding temperatures of 93 and $122{ }^{\circ} \mathrm{C}$ (fig. 14). In this depth range, the volatilization of existing hydrocarbon (Tissot and Welte, 1984, fig. V.1.10) increased from 200 to $1,000 \mathrm{ppm}$, and the nitrogen, sulfur, and oxygen compounds (resins, asphaltenes, and other heavy asphaltenic compounds) (Tissot and Welte, 1984, p. 189, 375-414) decreased sharply from 80 to 50 percent. The Carbon Preference Index value of n-alkanes dropped from 1.90 to 1.40; this drop indicates that stable n-alkanes increased in the hydrocarbons and that the montmorillonite was trans- formed into illite, thus producing a reduction in porosity of mudstone from 15 to 5 percent. Inevitably, water was formed by this transformation process and forced a large amount of preexisting hydrocarbons out from the source rocks (Chen and Wang, 1980). Chen and Wang (1980, p. 39) and Zhou (1981, p. 39) indicated that the lighter hydrocarbons were formed at depths ranging from 3,000 to $3,800 \mathrm{~m}$ and had corresponding temperatures of 122 and $155^{\circ} \mathrm{C}$. Condensate and wet gas formed generally at depths greater than $4,000 \mathrm{~m}$. These data conform with data given by Liang (1985) for the maturation of organic matter in the Huanghua depression.

Paraffin chromatography and pristane-phytane ratios measured in oil extracts and crude oils indicate that oil from the Gudao field was generated from source rocks of the third member of the Shahejie Formation (Chen and Wang, 1980, table 3).

\section{Reservoir Rocks}

The petroleum-producing reservoir rocks in the Jiyang depression are the Jurassic and Cretaceous clastic sequences, the sandstone and conglomeratic sandstone of the Paleogene Shahejie and Dongying Formations, the Neogene Guantao and Minghuazhen Formations, and the carbonate rocks of Ordovician and Paleogene age (Chen and Wang, 1980, table 1; Shuai and others, 1984).

Tertiary sandstone and conglomeratic sandstone in the Jiyang depression were deposited in a fluvial environment and are widely distributed in a sinuous, elongated pattern that has considerable variation in thickness. Commonly, the sandstone is rich in feldspar and is loosely cemented. This type of sandstone reservoir characterizes the Miocene Guantao Formation in the Gudao oil and gas field (approximate lat $37^{\circ} 52^{\prime} \mathrm{N}$., long $118^{\circ} 45^{\prime}$ E.) in the Zhanhua sag (figs. 13, 14; Chen and Wang, 1980). The porosity of the sandstone reservoir in the Gudao field ranges from 30 to 32 percent, and the effective permeability for oil ranges from 510 to 2,440 md (Chen and Wang, 1980, p. 486). However, the production capacities and the physical properties of the reservoir differ considerably between individual sandstone bodies (Chen and Wang, 1980). These textural changes can be attributed to variations in sedimentation in the fluvial environment.

The Gudao field is $70 \mathrm{~km}^{2}$ in area. The oil and gas pools of this field occur in sandstone of the Miocene Guantao Formation at a depth of $1,180 \mathrm{~m}$ (Petroconsultants Ltd., 1983). Oil and gas are trapped by a drape structure that overlies a horst block (fig. 14). The top seal consists of mudstone and shale. Laterally, the reservoir sandstone pinches out into shale and mudstone. In 1979 the initial recoverable oil reserves were estimated to be 700 million bbl, and in 1983 the initial recoverable gas reserves were estimated to be 2 trillion $\mathrm{ft}^{3}$ (Petroconsultants Ltd., 1983).

In the Jiyang depression, petroleum deposits also occur above and below the Paleogene-Neogene unconfor- 


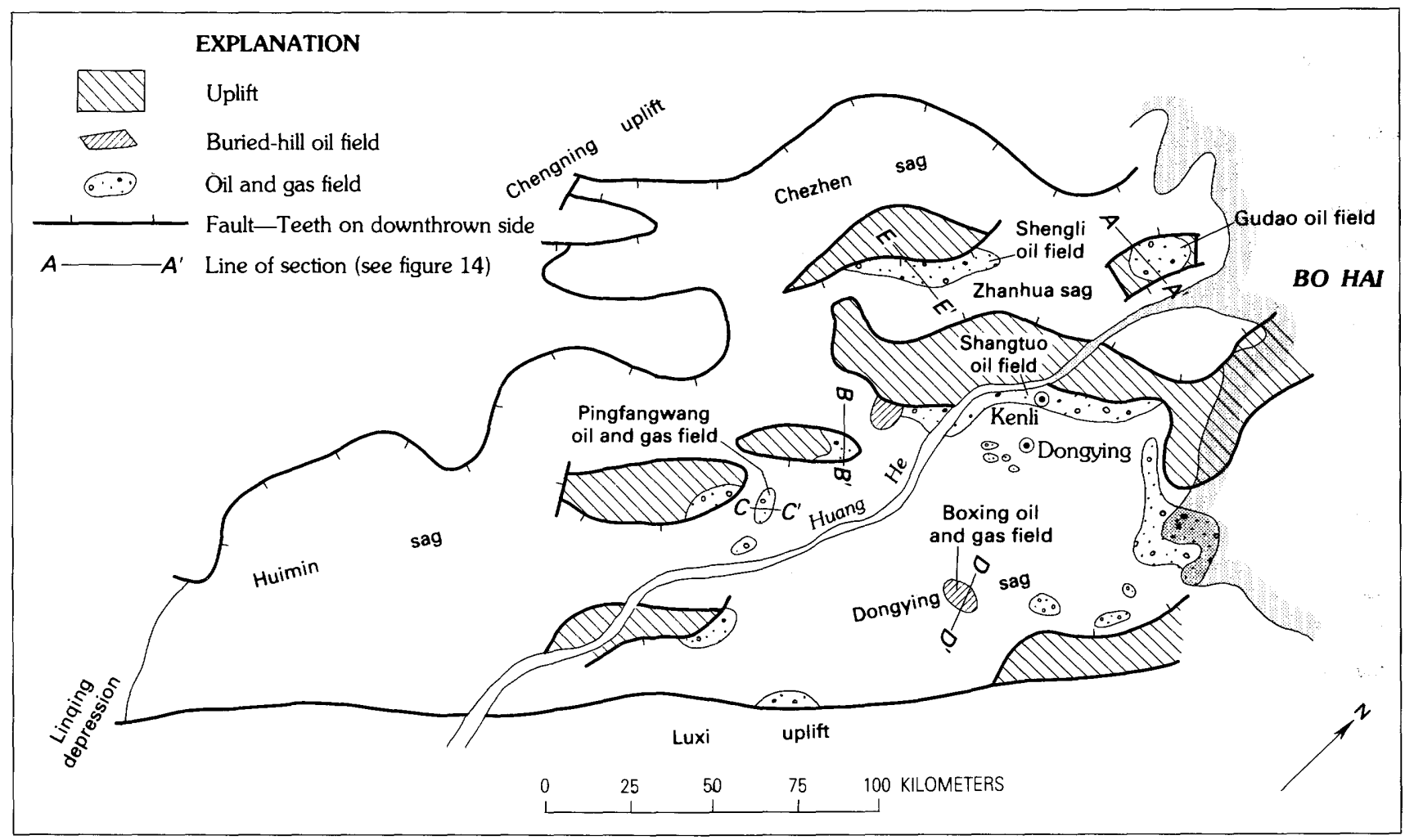

Figure 13. Principal structural units and oil and gas fields in the Jiyang depression, North China basin (modified from Chen and Wang, 1980; Petroconsultants Ltd., 1982; Shuai and others, 1984).

mity in sandstone bodies, such as the oil and gas pools located between the Oligocene Dongying and the Miocene Guantao Formations in the Huimin sag (fig. 14, pl. 2; Shuai and others, 1984). Lenticular Jurassic to Cretaceous sandstone bodies in reservoirs locally have provided continuous production in the Jiyang depression (Shuai and others, 1984, p. 7).

A Paleogene bioherm-type reservoir in the Pingfangwang field of the Dongying sag yields petroleum (approximate lat $37^{\circ} 21^{\prime}$ N., long $117^{\circ} 57^{\prime}$ E.; fig. 14; Petroconsultants Ltd., 1982; Ma, Ge, and others, 1982; Shuai and others, 1984, p. 4). The Paleogene bioherm consists chiefly of the Serpula-Cladesiphonia sinensis-bearing limestone of the third member of the Shahejie Formation. This oil- and gas-bearing reef limestone overlies source beds of the fourth member of the Shahejie Formation. The reservoir interval in the Pingfangwang field is about $160 \mathrm{~m}$ thick, and the porosity ranges from 36 to 43 percent. The depth to the top-pay beds is $1,410 \mathrm{~m}$ (Petroconsultants Ltd., 1983). The average daily output per well was reported in 1982 to be several hundred tons of oil (Petroconsultants Ltd., 1982). Buried-hill oil and gas pools in the Boxing field, which has good reservoir properties, occur in Ordovician dolomite (Shuai and others, 1984, p. 3-4).

\section{Bozhong Depression}

The Bozhong depression is located in the northern part of the North China basin and is bounded by the Liaodong Wan-Liao He depression on the north, the Jiyang depression on the south, the Huanghua depression on the west, and the Tanlu deep fracture system on the east (figs. 2,15 ). This depression is a graben structure (Chen and others, 1983, fig. 7; Li Desheng, 1984, fig. 3) and has an area of about $16,000 \mathrm{~km}^{2}$. The water depth in the entire Bo Hai ranges from about 18 to $50 \mathrm{~m}$. The maximum sedimentary cover of the Bozhong depression is about $9,980 \mathrm{~m}$ thick, of which about $7,270 \mathrm{~m}$ are Tertiary. Paleogene sedimentary rocks have a maximum thickness of $5,750 \mathrm{~m}$. Pre-Tertiary sedimentary rocks are about $2,710 \mathrm{~m}$ thick (pl. 2). Li Jiaqi (1984) identified 13 potential oil- and gasbearing sags and 10 buried-hill reservoirs in the Bozhong. These sags are separated from each other by uplifts. The depth to the top of the buried-hill reservoirs is generally less than 3,000 m (Li Jiaqi, 1984, p. 23).

\section{Source Rocks}

In the Bozhong depression, principal source rocks consist of lacustrine and paludal deposits of dark-gray 
METERS

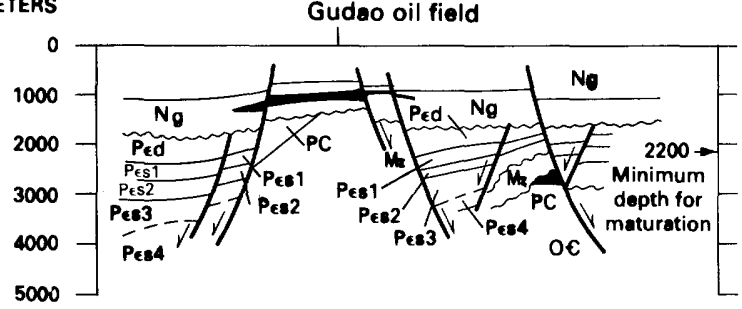

$\mathbf{N}$

$\mathbf{S}$

$\boldsymbol{B}$

$B^{\prime}$

METERS

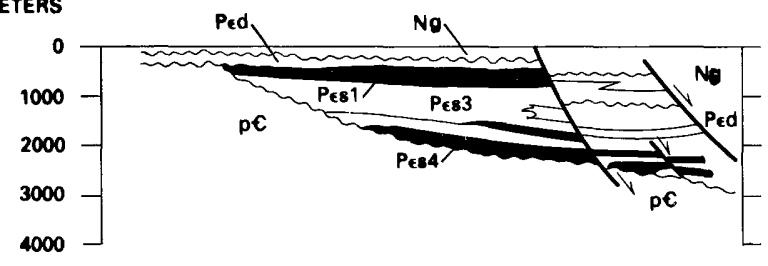

\section{EXPLANATION}

\begin{tabular}{|l|}
\hline Ng \\
\hline Ped \\
\hline
\end{tabular}

Guantao Formation (Neogene)

Dongying Formation (Paleogene)

Shahejie Formation (Paleogene)

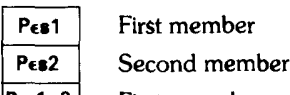

Pee1-2 First and second members, un differentiated

\begin{tabular}{|l|l}
\hline$P \in B_{1}$ & Third member-Reef limestone \\
\hline Pes4 & Fourth member
\end{tabular}

Pes1-4 Upper part of fourth member

Pes2-4 Lower part of fourth member

Pek Kongdian Formation (Paleogene)

Me Mesozoic deposits

PC. Permian and Carboniferous shale and siltstone

Ordovician limestone

OE Ordovician and Cambrian depositsChiefly carbonate rock

pC Precambrian rocks

Oil pool

Gas pool

Contact

Fault-Arrows show sense of relative movement

Angular unconformity
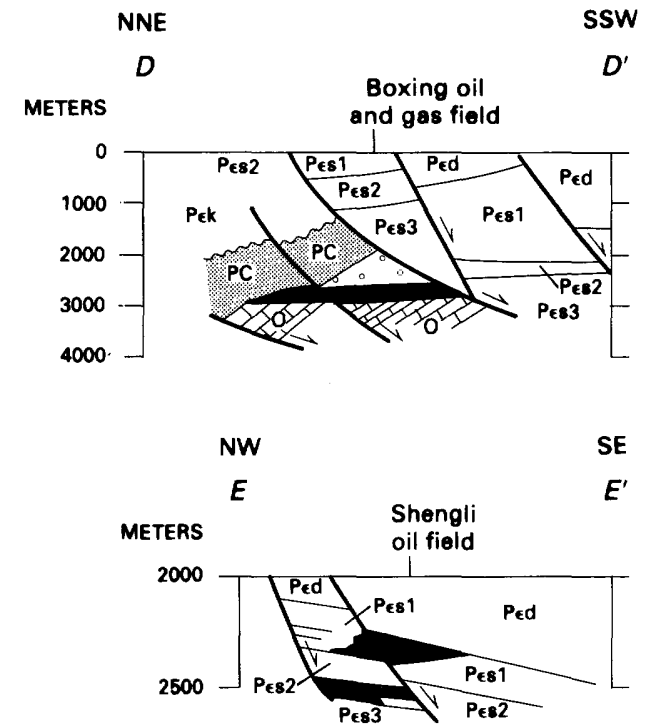

Figure 14. Schematic cross sections of principal oil and gas fields in the Jiyang depression, North China basin (modified from Chen and Wang, 1980; Shuai and others, 1984). Locations of sections shown on figure 13. 


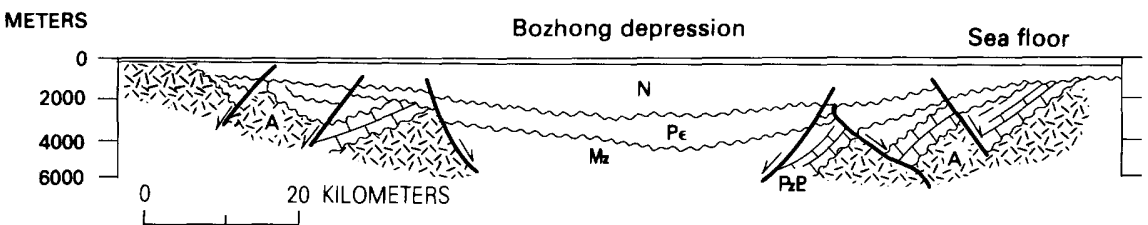

$\boldsymbol{A}$

\section{EXPLANATION}

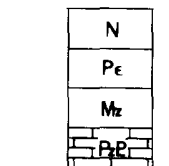

Neogene deposits

Paleogene deposits

Mesozoic deposits

Paleozoic and Proterozoic carbonate rocks

得 Archean granitic rocks

Contact

Fault-Arrows show sense of relative movement

Angular unconformity

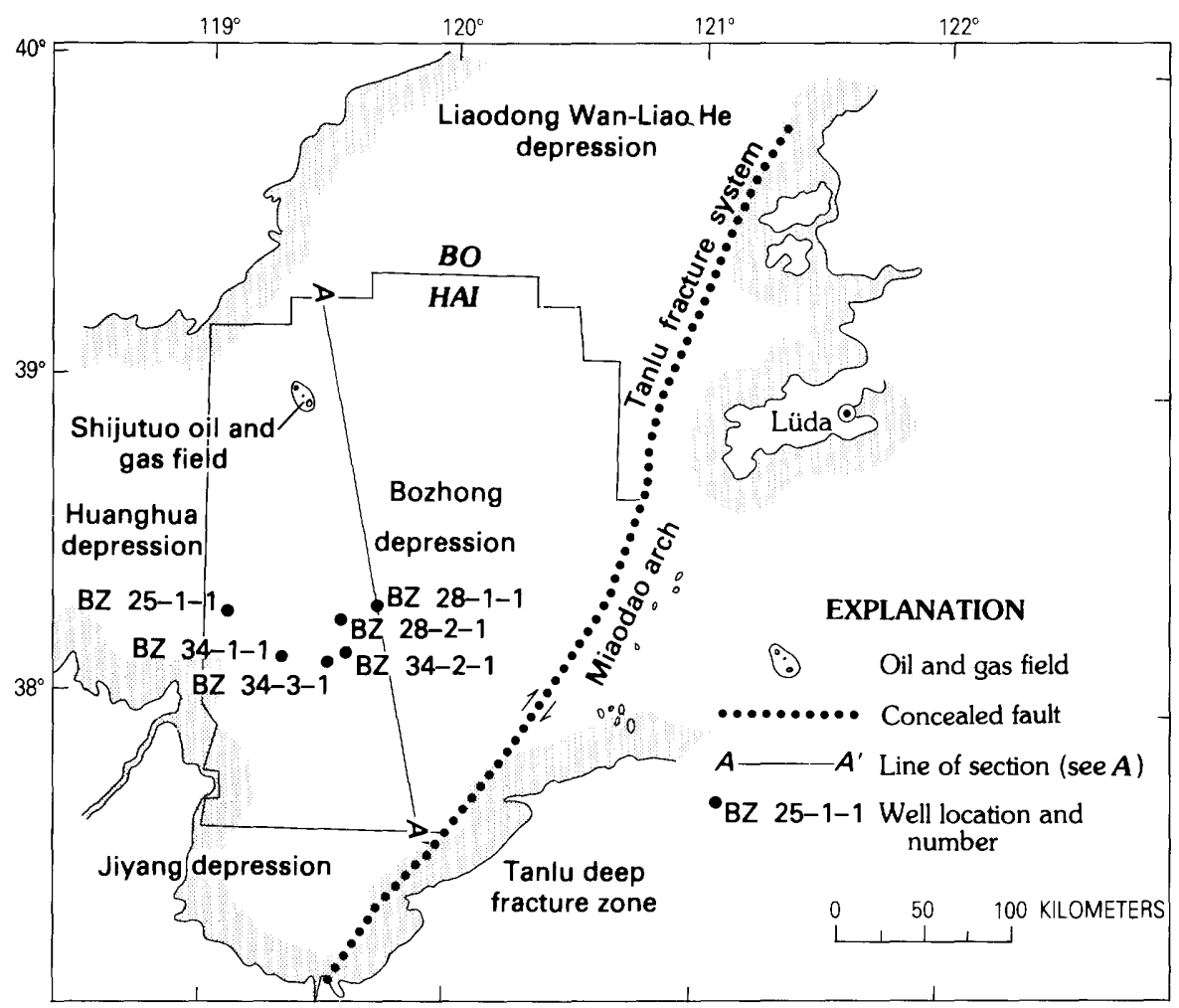

B

Figure 15. A, Schematic cross section of the Bozhong depression, North China basin; $B$, Principal structural units, oil and gas fields, and discovery wells (modified from Petroconsultants Ltd., 1981-84). 
mudstone, shale, and oil shale of the Paleogene Kongdian, Shahejie, and Dongying Formations. The fourth, third, and first members of the Shahejie, however, contain the major oil- and gas-generating strata of this depression (Petroconsultants Ltd., 1983; Xu and others, 1983).

Secondary source rocks are grayish-green mudstone and shale of Jurassic and Cretaceous age and coal beds of Carboniferous and Permian age. Hu and others (1982) inferred that oil and gas generated from this coal series is present throughout the Bozhong depression, as indicated by oil seeps and asphalt deposits from coal-bearing formations in nearby areas. Oil and gas also may have been generated from Cambrian and Ordovician carbonate rocks in the depression.

\section{Reservoir Rocks}

During the past several years, the Japan-China Oil Development Corporation and the China Petroleum Corporation have extensively explored the Bozhong depression and have discovered oil and gas pools in Jurassic, Cretaceous, and Tertiary sandstone, in Tertiary basalts and andesite, and in Cambrian, Ordovician, and Paleogene limestone and dolomite (Petroconsultants Ltd., 1981, 1983, 1984). Potential reservoir rocks of the depression are Carboniferous and Permian sandstone and conglomeratic sandstone, Middle and Late Proterozoic dolomite and limestone, and Archean plutonic and metamorphic rocks (fig. 15; Li Desheng, 1984).

The Tertiary sandstone reservoirs of the Bozhong are present in the following discovery wells: Bo Zhong 34-1-1 (lat $38^{\circ} 08^{\prime} 17^{\prime \prime}$ N., long $119^{\circ} 19^{\prime} 16^{\prime \prime}$ E.), Bo Zhong 34-2-1 (lat $38^{\circ} 08^{\prime} 00^{\prime \prime} \mathrm{N}$., long $119^{\circ} 34^{\prime} 00^{\prime \prime}$ E.), Bo Zhong 34-3-1 (lat $38^{\circ} 06^{\prime} 15^{\prime \prime}$ N., long $119^{\circ} 30^{\prime} 23^{\prime \prime}$ E.), and Bo Zhong 28-2-1 (lat $38^{\circ} 14^{\prime} \mathrm{N}$.; long $119^{\circ} 32^{\prime}$ E.) (fig. 15). Of these wells, the 3,823-m-deep Bo Zhong 34-2-1 well, which has a net reservoir thickness of $83 \mathrm{~m}$, shows better initial production test results. The test flow rate from the Bo Zhong $34-2-1$ is about $12,200 \mathrm{bbl} / \mathrm{d}$ of oil and 6.7 million $\mathrm{ft}^{3} / \mathrm{d}$ of gas, and the gas-oil ratio is $559 \mathrm{scf} / \mathrm{bbl}$ (standard cubic feet per barrel) (Petroconsultants Ltd., 1983). Oil and gas have accumulated in both structural and stratigraphic traps.

Tertiary limestone, basalt, and andesite reservoirs are located in the Shijutuo field (fig. 15; Petroconsultants Ltd. . 1984). According to Petroconsultants Ltd. (1984), the 1.2-km-long Shijutuo field (lat 38 $56^{\prime} 24^{\prime \prime}$ N., long $119^{\circ} 23^{\prime} 04^{\prime \prime}$ E.) is still being developed. The Bo Zhong No. 2 well in the Shijutuo field was drilled in 1975 to a depth of 3,097 m. Here the Tertiary limestone, basalt, and andesite have been fractured and produce oil and gas from a 30-m-thick reservoir interval. The initial test flow rate of the Bo Zhong No. 2 well is $1,120 \mathrm{bbl} / \mathrm{d}$ of oil and 1.3 million $\mathrm{ft}^{3} / \mathrm{d}$ of gas. In 1976, production tests from the single-well No. 9 platform were reported to yield 3,322 $\mathrm{bbl} / \mathrm{d}$ of oil. In 1981 , the seven-well No. 10 platform, located $1.2 \mathrm{~km}$ to the west, yielded $7,300 \mathrm{bbl} / \mathrm{d}$ of oil in production tests. The oil output from a single well completed in a basalt and andesite reservoir was reported to range between 700 and $2,000 \mathrm{bbl} / \mathrm{d}$. Porosity in the igneous reservoirs results from well-developed fractures and fumaroles. The API (American Petroleum Institute) gravity of the oil is $27^{\circ}$, and the gas-oil ratio is $1,160 \mathrm{scf} / \mathrm{bbl}$ (Petroconsultants Ltd., 1984).

The Jurassic and Cretaceous sandstone reservoir of the Bozhong depression is tapped by the Bo Zhong 25-1-1 well (lat $38^{\circ} 15^{\prime} 51^{\prime \prime} \mathrm{N}$., long $119^{\circ} 06^{\prime} 02^{\prime \prime}$ E.). The Bo Zhong 25-1-1 well was discovered in 1981 and is currently being evaluated (Petroconsultants Ltd., 1981). The depth to the top of the reservoir is $3,355 \mathrm{~m}$, and the maximum thickness of the reservoir is reported to be $4 \mathrm{~m}$. The initial flow rate in this well was $2,628 \mathrm{bbl} / \mathrm{d}$ of oil and $953,000 \mathrm{ft}^{3} / \mathrm{d}$ of gas (Petroconsultants Ltd., 1981).

In 1981, oil and gas were encountered in a buried hill of Cambrian and Ordovician limestone by the Bo Zhong 28-1-1 well (lat $38^{\circ} 17^{\prime}$ N., long $119^{\circ} 45^{\prime}$ E.) (Petroconsultants Ltd., 1981). The total depth of this well is $3,334.5 \mathrm{~m}$. The depth to the top of the reservoir is $2,975 \mathrm{~m}$, and the gross thickness of the reservoir interval is $323 \mathrm{~m}$. The interval between 3,200 and $3,300 \mathrm{~m}$ had an initial flow rate of 7,600 bbl/d of oil (Petroconsultants Ltd., 1981). This offshore discovery has a production potential of about 200,000 to $300,000 \mathrm{bbl} / \mathrm{d}$ of oil (Petroconsultants Ltd., 1981).

\section{Liaodong Wan-Liao He Depression}

The Liaodong Wan-Liao He depression is a graben system located along the lower reach of the Liao He and in most of the Liaodong Wan in the extreme northern part of the North China basin (figs. 2, 16). This depression is about $34,000 \mathrm{~km}^{2}$ in area, of which about $12,400 \mathrm{~km}^{2}$ are traversed by the lower reach of the Liao He (Zheng, 1984, p. 1). The maximum sedimentary fill in the depression is $12,060 \mathrm{~m}$, of which about $7,270 \mathrm{~m}$ are Tertiary. The maximum thickness of Paleogene sedimentary rocks is $5,750 \mathrm{~m}$ (pl. 2). Pre-Tertiary strata are about $4,790 \mathrm{~m}$ thick, and Quaternary sediments are about 727 m thick (Institute of Geology, Academia Sinica, 1958). During the past decade, petroleum exploration and development have been concentrated along the lower part of the Liao He. The lower reach of the Liao He contains the Damintun sag and the Eastern and Western sags, which are separated by a central rise of Archean granite (figs. 16, 17). The principal petroleum-producing oil and gas fields are located in the Western and Damintun sags, where they are bounded by a series of northeast-trending normal fault blocks (figs. 16, 17). 


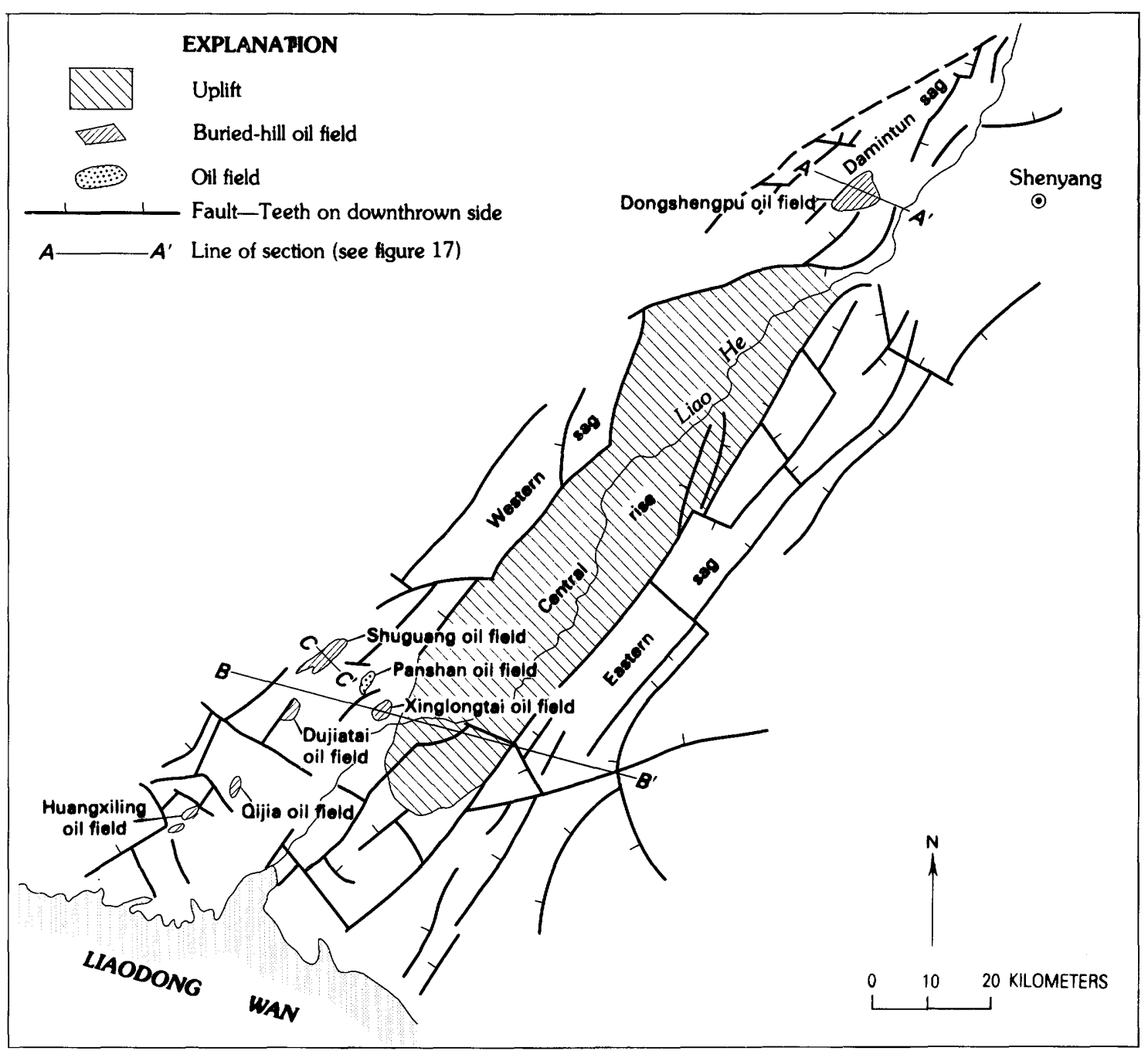

Figure 16. Principal structural units and oil fields in the Liaodong Wan-Liao He depression, North China basin (modified from Zheng, 1984).

\section{Source Rocks}

In the lower part of the Liao He depression, principal source rocks are the lacustrine dark-gray mudstone and oil shale of the Paleogene Shahejie and Dongying Formations. The fourth, third, and first members of the Shahejie Formation contain the major oil and gas source rocks (Wu, 1982, p. 154; Zheng, 1984, p. 13-14). Secondary source rocks in this depression are black to grayish-green mudstone and shale of Jurassic and Cretaceous age and coal beds of Carboniferous and Permian age. Source rocks in the Shahejie Formation are reported to be more than $1,750 \mathrm{~m}$ thick in about 65 to 85 percent of the depression (Zheng, 1984, p. 14). In these source rocks, the organic carbon content ranges from 1.74 to 2.81 weight percent, the extractable organic matter ranges from 547 to $1,029 \mathrm{ppm}$, the petroleum genetic potential ranges from 150 to $1,428 \mathrm{ppm}$, the hydrocarbon-organic carbon ratio ranges from 1.07 to 3.42 percent, and reduced sulfur is generally more than 0.5 percent (Zheng, 1984, p. 14). The kerogen varieties are sapropelic (type I) and mixed humic-sapropelic (type II) (Zheng, 1984). Wu and $\mathrm{Lu}(1983$, table 2) indicated that the maximum generation of oil was obtained between the depths of 2,000 and $2,400 \mathrm{~m}$. The geothermal gradient ranges from 3.29 to $4.65{ }^{\circ} \mathrm{C} / \mathrm{hm}$ in the western part of the depression and from 3.5 to $4.04{ }^{\circ} \mathrm{C} / \mathrm{hm}$ in the eastern part of the depression. Wang and others (1983, table 2-4-23) recognized a maximum geothermal gradient of $5{ }^{\circ} \mathrm{C} / \mathrm{hm}$. The variation in geothermal gradient is due to local igneous activity, which had accompanied sedimentation of the Tertiary source rocks (Wu and $\mathrm{Lu}, 1983$ ).

A comparison of pristane-phytane ratios, oil extracts and crude oils, and total hydrocarbon chromatography suggests that oil accumulations in the depression were generated from source rocks of the Paleogene Shahejie Formation (Zheng, 1984, p. 14). 


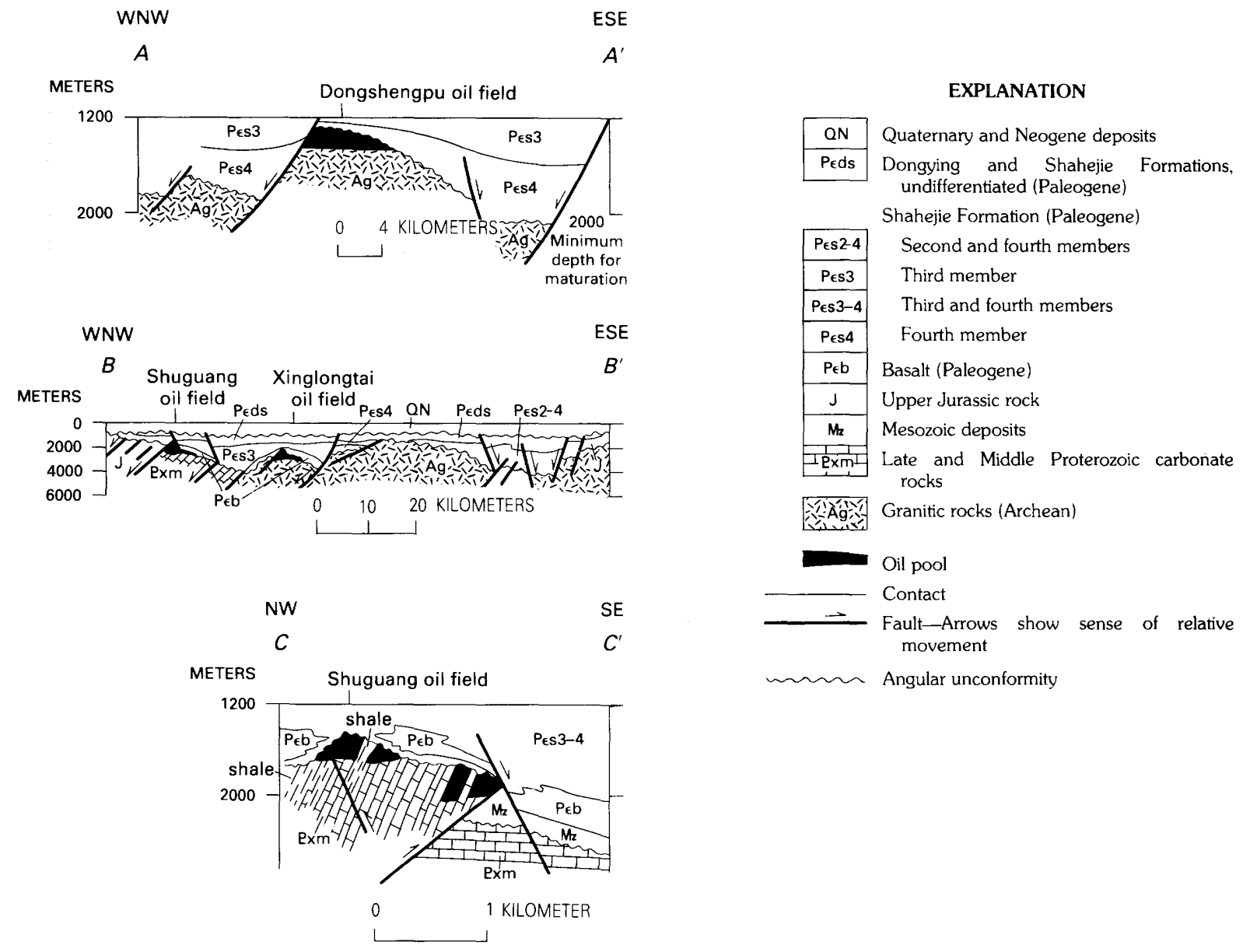

Figure 17. Schematic cross sections of principal oil fields in the Liaodong Wan-Liao He depression, North China basin (modified from Zheng, 1984). Locations of sections shown on figure 16.

\section{Reservoir Rocks}

The principal reservoir rocks in the Liaodong WanLiao He depression are (1) Archean granite, (2) Middle and Late Proterozoic dolomite, dolomitic limestone, and quartzite, (3) Jurassic and Cretaceous andesite, tuff, and volcanic breccia, and (4) sandstone of the Kongdian, Shahejie, Dongying, and Guantao Formations. The potential reservoir rocks are Carboniferous and Permian sandstone and volcanic rocks and Middle to Late Proterozoic, Cambrian to Ordovician, and Paleogene limestone and breccia (fig. 17, pl. 2; Ma, Ge, and others, 1982; Zhai and Zha, 1982; Zheng, 1984). The most productive oil and gas reservoirs in this depression are carbonate rock, volcanic rock, quartzite, and granite located in buried-hill accumulations of the Qijia, Shuguang, Dujiatai, Dongshengpu, and Xinglongtai oil fields (figs. 16, 17; Zheng, 1984, fig. 1).

A Tertiary sandstone reservoir is located in the Panshan oil field (lat $41^{\circ} 10^{\prime}$ N., long $122^{\circ} 00^{\prime}$ E.) (fig. 16; Petroconsultants Ltd., 1981). This field was discovered in 1964, and, between 1969 and 1975, a 100- $\mathrm{km}^{2}$ area was developed. By 1976, the average yield per well was 354 bbl/d of oil (Petroconsultants Ltd., 1981).

Jurassic and Cretaceous andesite and tuff reservoirs are located in a buried hill of the Qijia oil field (fig. 16; Zheng, 1984, fig. 1). The andesite and tuff of the buriedhill accumulation contain numerous fractures, fumaroles, and isolated caves. The bulk porosity of these rocks is greater than 10 percent, and the permeability is less than 1 md (Zheng, 1984, p. 13).

Middle and Late Proterozoic dolomite and quartzite reservoirs are located in the Shuguang and Dujiatai buriedhill oil fields (figs. 16, 17). The Shuguang oil field was discovered in 1979 and is $25 \mathrm{~km}^{2}$ in area (figs. 16, 17). Dolomite of Middle to Late Proterozoic age is the principal reservoir rock. The initial yield per well in the Shuguang field was $4,260 \mathrm{bbl} / \mathrm{d}$ of oil. New discovery wells drilled in the northwestern part of the Shuguang field in $1982 \mathrm{had}$ initial yields of $700 \mathrm{bbl} / \mathrm{d}$ of oil per well (Zheng, 1984).

Porosity in dolomite reservoirs ranges from 6.1 to 20.7 percent, and gas permeability is as much as $1,092 \mathrm{md}$ (Zheng, 1984, p. 9). The upper part of the dolomite 
generally is intensely leached. The leached zone overlies a solution-fracture zone that is characterized by cavities at the intersections of fractures. This solution-fracture zone is the most productive part of the buried-hill oil and gas pools in the Liaodong Wan-Liao He depression.

The Shuguang buried-hill oil pools are located on a horst block that has been covered by Paleogene source beds of the third and fourth members of the Shahejie Formation. This horst block is bounded on the west by a pre-Tertiary westerly dipping, northeast-trending normal fault and on the east by a Tertiary northerly dipping normal fault (fig. 17, cross section $B-B^{\prime}$; Zheng, 1984, p. 6-7). The horst block was broken by two intersecting pre-Tertiary faults in which the western fault of this set is probably a normal fault formed prior to the occurrence of the eastern reverse fault (fig. 17, cross section $C-C^{\prime}$ ). On the western and eastern flanks of the buried hill, the Shahejie source beds directly overlie Paleogene basalt, which in places unconformably overlies Jurassic and Cretaceous breccia. The reservoir of Middle to Late Proterozoic dolomite is intercalated with sandy dolomite, shale, marlstone, quartzose sandstone, and conglomerate and dips northwestward at about $41^{\circ}$. The shale and marl form excellent seals that partition the Shuguang field into four reservoirs: Shugu 1 and Shugu 40 in the east and Shugu 112 and Shugu 98 in the west (fig. 17; Zheng, 1984, p. 6).

The Shugu 1 and Shugu 40 dolomite reservoirs are separated by marlstone beds. Here the depth to the top of the pay zone is $1,684 \mathrm{~m}$, the depth to the oil-water contact is $2,000 \mathrm{~m}$, the gross thickness of the reservoir is about 316 $\mathrm{m}$, and the production rate of a single well ranges from 700 to $4,260 \mathrm{bbl} / \mathrm{d}$ of oil (Zheng, 1984, p. 6-7). The Shugu 98 and Shugu 112 sandy dolomite, quartzose, sandstone, and conglomerate reservoirs are separated by black shale beds. Here the depth to the top of the pay zone is $1,401 \mathrm{~m}$, the depth to the oil-water contact is $1,630 \mathrm{~m}$, the gross thickness of the reservoir is about $229 \mathrm{~m}$, and the production rate of a single well ranges from 350 to $700 \mathrm{bbl} / \mathrm{d}$ of oil (Zheng, 1984, p. 7).

The Dujiatai oil field was discovered in 1980. Middle to Late Proterozoic quartzite is the principal reservoir rock. The initial yield per well in this field ranges from 700 to $1,400 \mathrm{bbl} / \mathrm{d}$ of oil (Zheng, 1984, p. 2). Zheng (1984, p. 12) estimated from thin sections that the bulk porosity of the quartzite ranges from 0.4 to 7.7 percent and the air permeability through the quartz intergranular-pore spaces ranges from 5 to $10 \mathrm{md}$. Microfractures between 79 and 290 $\mu \mathrm{m}$ (microns) wide transect 60 to 100 percent of the quartzite reservoir (Zheng, 1984, p. 2).

Archean granite reservoirs are located in the Xinglongtai and Dongshengpu buried-hill oil and gas fields (figs. $16,17)$. The Xinglongtai oil and gas field, discovered in 1972, consists of gas-capped buried-hill oil pools in the deeply weathered Archean granite, Jurassic and Cretaceous breccia, and Paleogene conglomerate of the third member of the Shahejie Formation. The oil and gas accumulations are sealed by a normal fault along the northwest flank of the field (Zhai and Zha, 1982, fig. 8). Initial production from this field was 210 to $700 \mathrm{bbl} / \mathrm{d}$ of oil and 3.531 million $\mathrm{ft}^{3} / \mathrm{d}$ of gas (Zheng, 1984, p. 2). Zhai and Zha (1982, p. 3-6) mentioned that the granite reservoirs of the buried-hill pools produce about $420 \mathrm{bbl} / \mathrm{d}$ per well. Zheng $(1984$, p. 13) estimates the porosity of the deeply weathered and highly fractured gneissic granite to be 8 percent.

The Dongshengpu oil and gas field was discovered in 1983. Granite is the principal reservoir in this buried-hill oil and gas pool. This field is controlled by a horst block bounded on the west by a Paleogene normal fault that has a $1,400-\mathrm{m}$ displacement and bounded on the east by a northeast-trending late Paleogene normal fault that has about 200 to $400 \mathrm{~m}$ of displacement (figs. 16, 17; Zheng, 1984, fig. 3). Generally, the depth to the top of the production zone is $2,600 \mathrm{~m}$. The closure of the buried-hill granite is $800 \mathrm{~m}$ across an area of $15 \mathrm{~km}^{2}$ (Zheng, 1984, p. 4). The entire reservoir is covered by blackish-gray source beds of the third and fourth members of the Paleogene Shahejie Formation. The daily output from a single well, Sheng No. 11, was $10,500 \mathrm{bbl} / \mathrm{d}$ of oil and 3.354 million $\mathrm{ft}^{3} / \mathrm{d}$ of gas (Zheng, 1984, p. 2).

\section{Potential}

The North China basin covers an area of about $213,000 \mathrm{~km}^{2}$, of which the six principal petroleumproducing depressions occupy $94,400 \mathrm{~km}^{2}$. An estimate of the volume of sediment fill in these six depressions is $472,000 \mathrm{~km}^{3}$, which represents about 56 percent of the total volume of sedimentary fill in the basin. Adequate quantities of rich source rocks appear to be present throughout the North China basin. An estimated ultimate oil and gas recovery from the individual petroleum-producing depressions in the North China basin is shown in table 3. The Jiyang depression ranks first in oil reserves, followed generally by the Jizhong, Huanghua, Dongpu-Kaifeng, Liaodong Wan-Liao He, and Bozhong depressions. The currently known, ultimate recoverable reserves are 11.251 billion bbl of oil and 8.425 trillion $\mathrm{ft}^{3}$ of gas (table 3 ). In the southern part of the North China basin, significant gas resources will be obtained from the source rocks of the Carboniferous to Permian coal series (Zhu and $\mathrm{Xu}, 1984$ ).

\section{Coal}

\section{General Statement}

The coal deposits of the North China basin occur chiefly in the Carboniferous to Permian sequence and locally in the Jurassic to Cretaceous sequence in the Jizhong, Bozhong, and Liaodong Wan-Liao He depressions 
Table 3. Estimated ultimate oil and gas recovery from discovered fields in the North China basin

[Modified from William D. Dietzman, Energy Information Administration, Department of Energy, unpub. data, 1987]

\begin{tabular}{|c|c|c|}
\hline Name of depression & $\begin{array}{c}\text { Oil } \\
\text { (million bbl) }\end{array}$ & $\begin{array}{c}\text { Gas } \\
\left(\text { billion } \mathrm{ft}^{3}\right)\end{array}$ \\
\hline Jizhong . . . . . . . & 2,455 & 3,750 \\
\hline Dongpu-Kaifeng.............. & 977 & 500 \\
\hline Huanghua........ & 1,107 & 470 \\
\hline Jiyang $\ldots \ldots \ldots \ldots \ldots \ldots \ldots \ldots$ & 5,398 & 3,350 \\
\hline Bozhong.$\ldots \ldots \ldots \ldots \ldots \ldots \ldots$ & 240 & 65 \\
\hline Liaodong Wan-Liao He .......... & 651 & 100 \\
\hline \multirow{2}{*}{$\begin{array}{l}\text { Location unknown } \ldots \ldots \ldots \ldots \ldots \\
\quad \text { Total. } \ldots \ldots \ldots \ldots \ldots \ldots \ldots\end{array}$} & 423 & 190 \\
\hline & 11,251 & 8,425 \\
\hline
\end{tabular}

(pls. 1, 2). Both the Carboniferous to Permian and the Jurassic to Cretaceous coal-bearing sequences were found in the basin during exploratory drilling for petroleum (fig. 18). The discussion of the stratigraphy of these coal-bearing sequences is based chiefly on information obtained from coal mining areas around the perimeter of the basin (Han and Yang, 1980; Department of Coal Teaching and Researches, 1981).

\section{Occurrence}

The Carboniferous to Permian coal series is composed of the Late Carboniferous Benxi and Taiyuan Formations, the Early Permian Shanxi and lower part of the Shihezi Formations, and the Late Permian upper part of the Shihezi Formation (table 4). The depositional environments of these coal-bearing formations are listed in table 4 and figure 19.

The site of the North China basin was a large platform landmass that had been exposed to a lengthy period of extensive weathering and erosion from the Late Ordovician to the Late Carboniferous. In the early Late Carboniferous, as this landmass subsided, the Benxi sea encroached from the east and covered most of the area. Detrital sediments derived from the surrounding highlands were deposited in shallow-marine and littoral-marine environments. In the North China basin, the Benxi Formation consists of 80 to $120 \mathrm{~m}$ of sandstone, siltstone, and mudstone intercalated with coal beds and local fossiliferous limestone (Han and Yang, 1980, p. 107-110; Department of Coal Teaching and Researches, 1981, v. 2, p. 58 ).

Throughout the North China basin, the Taiyuan coal-bearing sequence was deposited during the transgression of the Carboniferous sea and the regression of the latest Carboniferous and Permian sea. The Taiyuan Formation consists of 30 to $70 \mathrm{~m}$ of sandstone, siltstone, mudstone, and marlstone intercalated with fossiliferous limestone and thin- to thick-bedded coal of littoral-marine to transitionalmarine origin. The Taiyuan Formation contains the highest quality commercial-grade bituminous coal deposits in the
North China basin. The coal beds, which are concentrated in the northern, western, and southern parts of the basin, range in thickness from 5 to $10 \mathrm{~m}$. Large coal mines in the thick coal beds of the Taiyuan Formation are located near the basin border in the Hebei, Henan, and Shandong provinces (fig. 19, pl. 1).

During the Early Permian, the Late Carboniferous sea withdrew toward the south, and the coal-bearing sequence of the Shanxi was deposited conformably on the Taiyuan Formation. In the North China basin, the Shanxi Formation is continental to transitional marine in origin and consists of less than $100 \mathrm{~m}$ of sandstone intercalated with siltstone, mudstone, and locally, in the upper part of the sequence, beds of limestone and lenticular mudstone. These detrital sedimentary rocks contain coal beds 3 to $10 \mathrm{~m}$ thick that were deposited in fluvial-channel, overbank, lacustrine, marsh, swamp, lagoonal, and coastal-deltaic environments. Mineable, good-quality bituminous coal beds in the Shanxi Formation occur in the northern, western, and southern parts of the North China basin (fig. 19; Department of Coal Teaching and Research, 1981, v. 2, fig. III-60).

During late Early Permian to early Late Permian time, coal-bearing sedimentary rocks of the lower part of the Shihezi and the upper part of the Shihezi Formation were deposited. The Shihezi Formation conformably overlies the Shanxi Formation. In most of the North China basin, the Shihezi Formation consists of continental detrital sedimentary rocks containing thin coal beds. Mineable coal beds are located in the continental- and transitional-marine sequences in the southern part of the basin (Department of Coal Teaching and Researches, 1981, v. 2, p. 64-67). The coal-bearing sequences of the Shihezi Formation in the southern part of the basin are near the southern and southeastern borders of the basin and are confined chiefly to Henan province, where they are extensively mined (pl. 1). The coal beds are 5 to $10 \mathrm{~m}$ thick but locally may be 10 to $30 \mathrm{~m}$ thick.

During the early Mesozoic, most of the area of the present-day North China basin was an emergent landmass, but from Late Jurassic through Cretaceous time, the landmass was broken by northeast-trending extensional faults that formed numerous small and shallow depressions throughout the basin. These depressions were filled with molasse deposits composed of detrital sedimentary rocks, volcanic flows, and, locally, thin coal beds (Hu and others, 1982).

\section{Potential}

High-quality bituminous coal and anthracite of Carboniferous and Permian age are concentrated in the northern, western, and southern parts of the basin. The burial depth to the top of the Carboniferous to Permian sequence ranges from about $1,500 \mathrm{~m}$ to more than $6,000 \mathrm{~m}$ (fig. 18, pl. 1; Chang and others, 1981). Most of the coal beds are deeper than $1,800 \mathrm{~m}$ and therefore are excluded from coal 


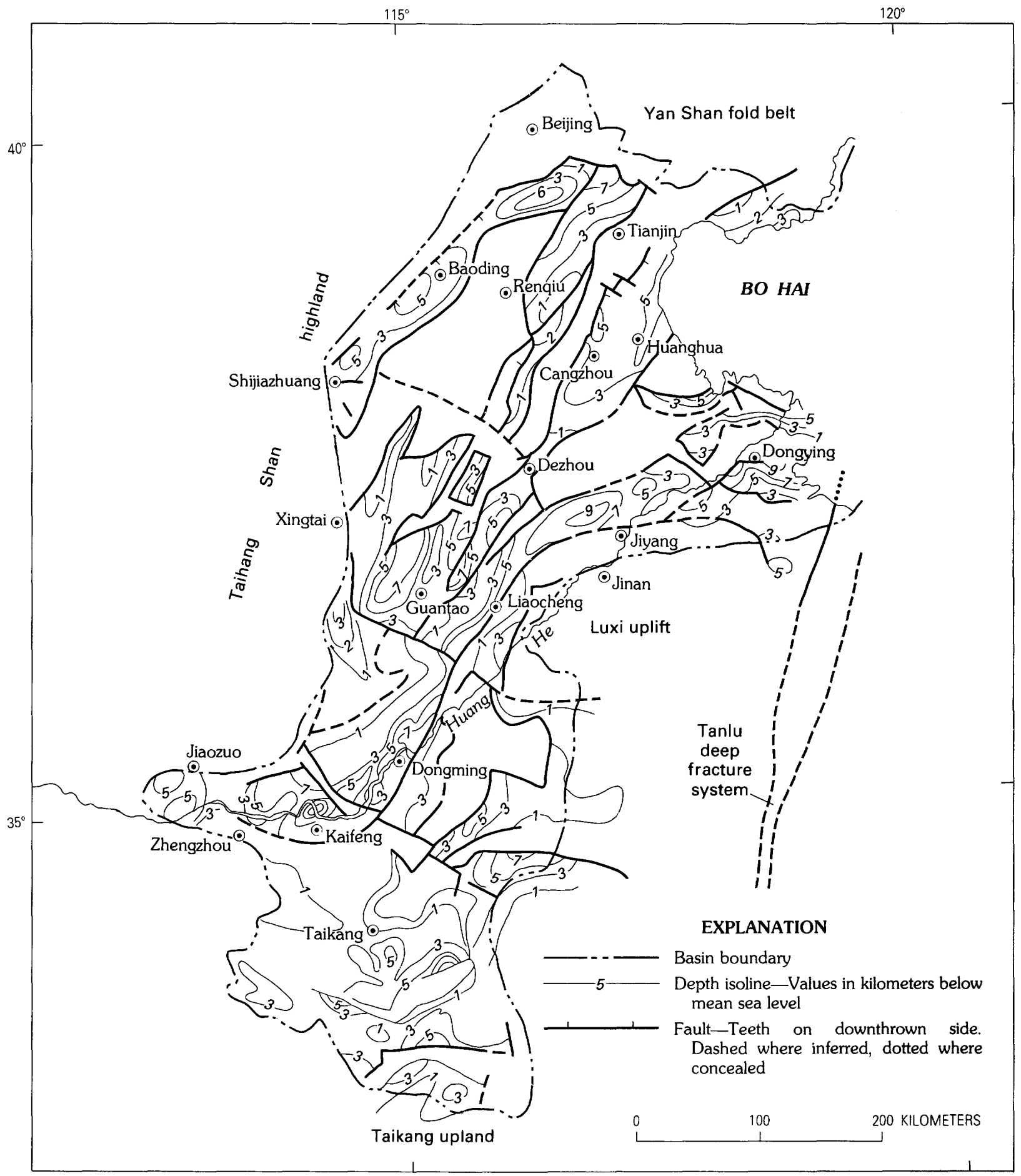

Figure 18. Depth to the top of the Carboniferous and Permian strata in the principal part of the North China basin (modified from Chang and others, 1981).

resource consideration (Wood and others, 1983, p. 23-24). China's coal reserves total 642.5 billion tons, 411.3 billion tons of which are located in the North China region. The North China basin occupies about one-third of the total area of North China, and the coal reserves in the basin are estimated to be 170 billion tons, about 30 percent of the coal reserves of the North China region (International Petroleum Encyclopedia, 1985, p. 30). 
Table 4. Carboniferous and Permian stratigraphy of the North China basin

[Modified from Department of Coal Teaching and Researches, 1981, v. 2, table III-8; Han and Yang, 1980, v. 2, p. 101-152]

\begin{tabular}{|c|c|c|c|}
\hline System & Series & Formation & Depositional environment \\
\hline \multirow{4}{*}{ Permian } & \multirow[b]{2}{*}{ Late Permian } & Shiqianbeng & Continental red beds. \\
\hline & & $\begin{array}{l}\text { Upper part of } \\
\text { the Shihezi }\end{array}$ & \multirow{2}{*}{$\begin{array}{l}\text { Chiefly continental lithofacies, locally } \\
\text { interfingering with continental and } \\
\text { marine-transitional facies during south- } \\
\text { ward regression of the sea in Permian } \\
\text { time. Fluvial, lake, marsh, and swamp } \\
\text { deposits north and deltaic littoral- } \\
\text { marine, lagoonal, and neritic-marine } \\
\text { deposits south. }\end{array}$} \\
\hline & \multirow{2}{*}{ Early Permian } & $\begin{array}{l}\text { Lower part of } \\
\text { the Shihezi }\end{array}$ & \\
\hline & & Shanxi & $\begin{array}{l}\text { Regressive deposits of neritic- to littoral- } \\
\text { marine, lagoonal, deltaic, fluvial. lake, } \\
\text { marsh, and swamp environments. }\end{array}$ \\
\hline \multirow[t]{2}{*}{ Carboniferous } & \multirow{2}{*}{$\begin{array}{l}\text { Late } \\
\text { Carboniferous }\end{array}$} & Taiyuan & $\begin{array}{l}\text { Transgressive deposits of shallow-marine, } \\
\text { littoral-marine, lagoonal, deltaic, flu- } \\
\text { vial, lake, marsh, and swamp environ- } \\
\text { ments. }\end{array}$ \\
\hline & & Benxi & $\begin{array}{l}\text { Transgressive deposits. Shallow-marine } \\
\text { and littoral-marine environments. }\end{array}$ \\
\hline
\end{tabular}

North bhina basin

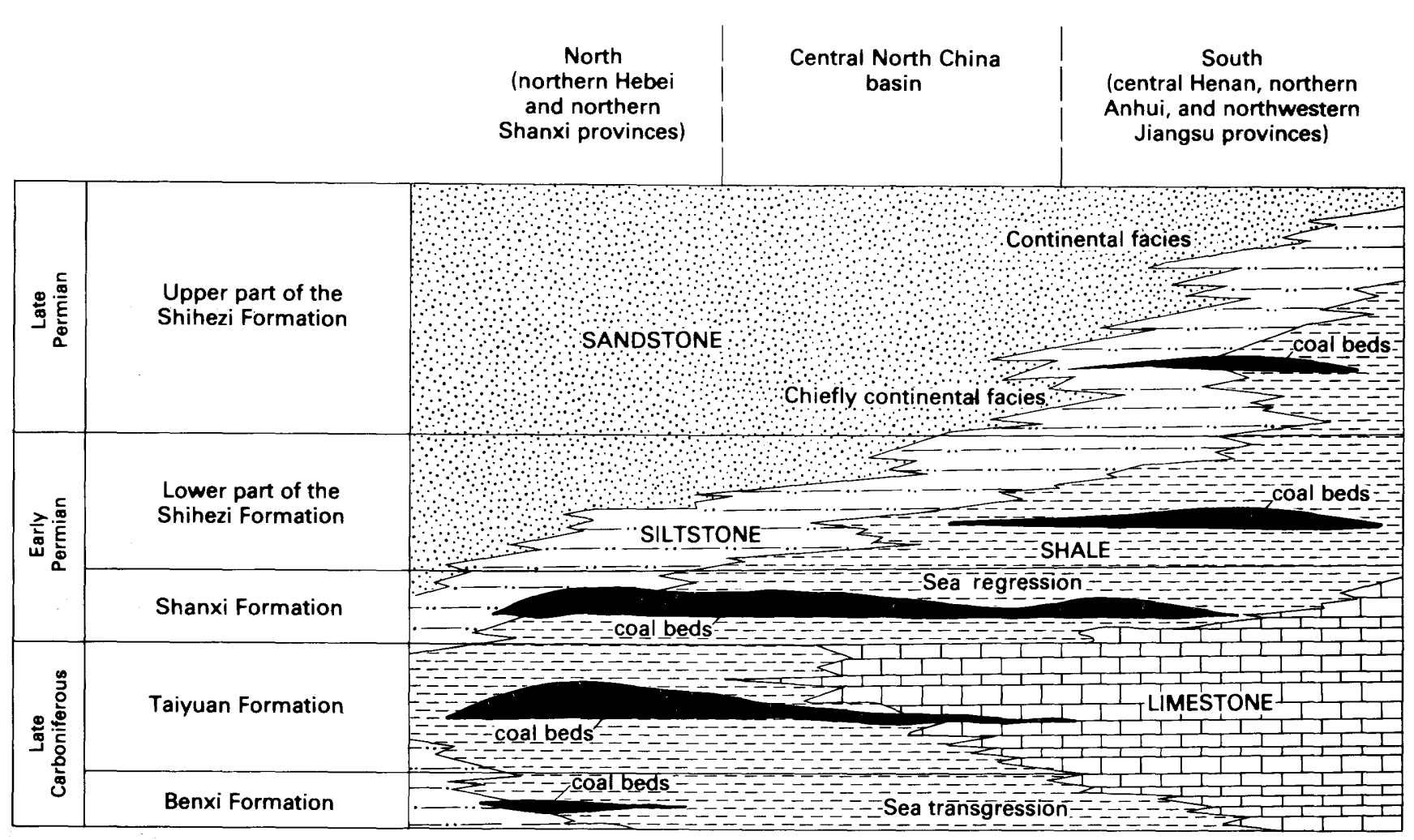

Figure 19. Lithofacies distribution of the Carboniferous to Permian coal series in the principal part of the North China basin (modified from Han and Yang, 1980). 


\section{SUMMARY AND CONCLUSIONS}

The intracratonic North China basin evolved by differential rifting and regional block faulting, accompanied by gravity slumping, during the latest episode of the Jurassic and Cretaceous Yanshanian orogeny to the Miocene Himalayan orogeny. Geophysical data and igneous activity in the region suggest that this taphrogenic stress was caused by upward advection of the asthenosphere. In the basin, the high geothermal gradients caused source rocks of the Paleogene Shahejie Formation to reach maturation stage at a depth of burial of about $2,000 \mathrm{~m}$. Later, during the late Paleogene and early Neogene, oil and gas migrated, as a result of a compression torsional "push" from the southwest, through permeable detrital rocks and along fractures, faults, and unconformities and accumulated in stratigraphic and structural traps.

Thick coal beds in the Carboniferous to Permian sequence are the major source rocks for natural gas in the southern part of the basin. The gas fields in the DongpuKaifeng depression can help to guide further exploration for additional gas resources in the Dongpu-Kaifeng depression and adjacent depressions of the basin.

Archean granite, Middle and Late Proterozoic, Cambrian, and Ordovician dolomite, and Tertiary delta-front sandstone are the dominant reservoirs in the basin. Dolomite and granite reservoirs are situated in fault-controlled buried-hill highs that are covered by source beds of the Paleogene Shahejie Formation and provide the principal petroleum-producing areas in the North China basin. The Tertiary sandstone reservoirs, however, generally have a constrained production capacity because of rapid changes in the lithofacies of the fluvial sandstone bodies throughout the basin. Future discoveries from buried hills of the Archean granite are likely to be made in the offshore part of the Liaodong Wan-Liao He, Bozhong, and Jiyang depressions. Future discovery of oil is highly likely in the buried hills of Middle and Late Proterozoic dolomite in the Huanghua depression. The ultimate recoverable oil and gas reserves total 11.251 billion bbl of oil and 8.425 trillion $\mathrm{ft}^{3}$ of gas in the petroleum-producing depressions of the North China basin.

Most of the coal beds are generally excluded as an energy resource because the overburden is very thick. Nevertheless, coal-bed methane is a large, potential gas resource. In the North China region, the North China basin has an estimated 170 billion tons of coal reserves, which is about 41 percent of the total regional coal reserves ( 411.3 billion tons). In the years ahead, underground coal mining near the border of the basin will be extensive, particularly in the Taikang upland of the southern part of the basin.

\section{REFERENCES CITED}

Bai Songzhang and Wang Sue, 1984, Types of pools in carbonate rocks in North China and their production characteristics: Acta Petrolei Sinica, v. 5, no. 3, p. 43-55.

Cai Qianzhong, 1983, Geological conditions of PermoCarboniferous coal-formed gas in North China platform and its prospects: Oil and Gas Geology, v. 4, no. 1, p. 34-44 [in Chinese with English abstract].

Chang Xiaozhe, Zhen Yichuen, Xie Chenkan, and Yang Fuxin, 1981, The prospect of Permo-Carboniferous coal-formed gas in North China: Oil and Gas Geology, v. 2, no. 4, p. 341-350 [in Chinese with English abstract].

Chen Changming, Huang Jiakuan, Chen Jingshan, Tian Xinggou, Chen Ruijun, and $\mathrm{Li} \mathrm{Li,} \mathrm{1983,} \mathrm{Evolution} \mathrm{characteristics} \mathrm{of}$ the syntectonic deposition of the Tertiary Bohai rift system, in Zhu Xia, ed., Evolution and structure of the Mesozoic and Cenozoic basins in China: Beijing, China, Science Press, p. 114-120 [in Chinese].

Chen Sizhong and Wang Ping, 1980, Geology of Gudao oil field and surrounding areas, in Halbouty, M.T., ed., Giant oil and gas fields of the decade 1968-1978: American Association of Petroleum Geologists Memoir 30, p. 471-486.

Chen Xiaodong, Zhou Jizhi, Qiu Yanghui, and Guo You, 1984, Petroleum geology features of Dongming depression: Oil and Gas Geology, v. 5, no. 4, p. 373-384 [in Chinese with English abstract].

Chinese Academy of Geological Sciences, 1976, Geologic map of the People's Republic of China: Beijing, China, Cartographic Press, scale 1:4,000,000, one sheet [in Chinese].

1982, An outline of the stratigraphy in China: Beijing, China, Geological Publishing House, v. 1, 445 p. [in Chinese with English abstract].

Defense Mapping Agency, 1979, Gazetteer of the People's Republic of China: Washington, D.C., U.S. Government Printing Office, $916 \mathrm{p}$.

Deng Qidong, Chen Yihui, Wang Jingbo, Jiang Pu, Wang Yipeng, Xiang Jiacui, and Wang Chunhua, 1984, The seismotectonical characteristics of the North China fault block region and its dynamical co-operating model, in The Organizing Committee of ISCSEP, A collection of papers of International Symposium on Continental Seismicity and Earthquake Prediction (ISCSEP): Beijing, China, Seismological Press, p. 243-263.

Department of Coal Teaching and Researches, Wuhan College of Geology, 1981, Coal geology: Beijing, China, Geological Publishing House, v. 2, 296 p. [in Chinese].

Ding Guoyu, 1984, Active faults in China, in The Organizing Committee of ISCSEP, A collection of papers of International Symposium on Continental Seismicity and Earthquake Prediction (ISCSEP): Beijing, China, Seismological Press, p. 225-242.

Fei Qi and Wang Xie-Pei, 1984, Significant role of structural fractures in Renqiu buried-hill oil field in eastern China: American Association of Petroleum Geologists Bulletin, v. 68 , no. 8 , p. $971-982$. 
Fu Jiamo and Jia Rongfen, 1984, Preliminary study on characteristics of organic geochemistry of carbonate source rocks and evaluation of oil and gas in China: Beijing Petroleum Geology Symposium, September 1984, 16 p. [reprint].

Han Dexin and Yang Qu, eds., 1980, Coal geology of China: Beijing, China, Coal Industry Press, v. 2, 415 p. [in Chinese].

Hao Shihsheng and Zhang Changgen, 1984, The primary hydrocarbon characteristics of the Middle-Upper Proterozoic in the northern part of North China: Beijing Petroleum Symposium, September 1984, 31 p. [reprint].

Hellinger, S.J., Shedlock, K.M., Sclater, J.G., and Ye Hong. 1985, The Cenozoic evolution of North China basin: Tectonics, v. 4, no. 4, p. 343-358.

Hu Jianyi, Tong Xiaoguang, Xu Shubao, and Lin Dianzhong, 1982, Tectonic framework and oil possibilities of Mesozoic rocks in the Bohai Bay and its neighborhood: Acta Petrolei Sinica; v. 3, no. 2, p. 1-8 [in Chinese with English abstract].

Huang Jiqing, Ren Jishun, Jiang Chunba, Zhang Zhengkun, and Qin Deyu, 1980, The geotectonic evolution of China: Beijing, China, Science Press, 120 p. [English translation distributed by Springer-Verlag, Berlin, New York, 203 p.]

Institute of Geology, Academia Sinica, 1958, Regional stratigraphy of China, Supplement: Beijing, China, Science Press, 190 p. [in Chinese].

International Petroleum Encyclopedia, 1985, China outlook, China opens doors to equipment technology: Tulsa, Oklahoma, Pennwell Publishing Co., v. 18, p. 7-33.

Lee, K.Y., 1970, Some rare-element mineral deposits in mainland China: U.S. Geological Survey Bulletin 1312-N, p. N1-N34.

Li Desheng, 1979, Structural patterns of the petroliferous basins in the Bohai Bay: Shiyou Kantan Yu Kaifa [Petroleum Exploration and Development], no. 2, p. 1-101 [in Chinese].

1980. Geology and structural characteristics of Bohai Bay, China: Acta Petrolei Sinica, v. 1, no. 1, p. 6-20 [in Chinese with English abstract].

1982, Tectonic types of oil and gas basins in China: Acta Petrolei Sinica, v. 3, no. 3, p. 1-12 [in Chinese with English abstract].

1984, Geologic evolution of petroliferous basins on continental shelf of China: American Association of Petroleum Geologists, v. 68, no. 8, p. 993-1003.

Li Desheng, Du Yonglin, and Hu Guonong, 1984, Petroleum geological characteristics of Langfang-Guan basin, BeijingTienjing region: Beijing Petroleum Geology Symposium. September 1984, 25 p. [reprint].

Li Desheng and Xue Shuhao, 1983. The Eastern China MesozoicCenozoic basins and hydrocarbon occurrence: Acta Geologica Sinica, v. 57, no. 3, p. 224-234 [in Chinese with English abstract].

Li Jiaqi, 1984, The primary factors causing gravity and magnetic anomalies of the Bohai Sea: Marine Geology and Quaternary Geology, v. 4, no. 4, p. 21-34 [in Chinese with English abstract].
Liang Fuhua, 1985, Characteristics of hydrocarbons from Huanghua depression: Acta Petrolei Sinica, v. 6, no. 1, p. 17-23 [in Chinese with English abstract].

Liang Fuhua, Liu Tianzhong, and Cao Yan, 1981, A comparative study of the characteristics of source rocks and oil sources in central Huanghua depression: Acta Petrolei Sinica, special issue, v. 2, no. 4, p. 75-82 [in Chinese with English abstract].

Lin Dianzhong, 1982, The shear structure features in Bohai Bay oil and gas-bearing basin: Oil and Gas Geology, v. 3, no. 1, p. 16-24 [in Chinese with English abstract].

Liu Xun, Xu Zhiqing, and Huang Huaizeng, 1981, Some characteristics of tectonic evolution of Cretaceous-Paleogene basins in eastern China: Institute of Geology, Chinese Academy of Geological Sciences, Contributions to the Tectonics of China and Adjacent Regions, p. 55-76 [in Chinese with English abstract].

Ma Li, Ge Taisheng, Zhao Xueping, Zie Taijun, Ge Rong, and Dang Zhenrong, 1982. Oil basins and subtle traps in the eastern part of China, in Halbouty, M.T., ed., The deliberate search for the subtle trap: American Association of Petroleum Geologists Memoir 32, p. 287-315.

Ma Xingyuan, Deng Qidong, Wang Yipeng, and Liu Hefu, 1982. Cenozoic graben system in North China: Annals of Geomorphology Supplement, v. 42, p. 99-116.

Ma Xingyuan, Liu Guodong, and Su Jian, 1984, The structure and dynamics of the continental lithosphere in north-northeast China: Annales Geophysicae, v. 6, no. 6, p. 611-620.

Ma Xingyuan, Liu Hefu, Wang Weixiang, and Wang Yipeng, 1983, Meso-Cenozoic taphrogeny and extensional tectonics in Eastern China: Acta Geologica Sinica, v. 57, no. 1, p. 22-32 [in Chinese with English abstract].

Ma Xingyuan, Zhang Jiasheng, Bai Jin, and Suo Shutien, 1984, Variations in tectonic style through the Precambrian history of China: Journal of Geodynamics, no. 1, p. 221-249.

Masters, C.D., Girard, O.W., Jr., and Terman, M.W., 1980, A perspective on Chinese petroleum geology: Southwestern Legal Foundation. Proceedings, Exploration and economics of the petroleum industry, v. 18, p. 199-225.

Meyerhoff, A.A., 1982. Petroleum basins of the Union of Soviet Socialist Republics and the People's Republic of China and the politics of petroleum: Petroleum Exploration Society of Australia, Distinguished Lecture Series, 140 figs., 341 p.

Petroconsultants Ltd., 1977, 1981, 1982, 1983, 1984, Oil and gas data sheets: Geneva, Switzerland, 4 pages each.

Regional Stratigraphic Editorial Section of the Hebei Province and Tianjin Region, 1979a, Stratigraphy of the Hebei Sheng and Tianjin Shi: Beijing, China, Geological Publishing House, Regional stratigraphic tables of North China, v. 1, 312 p. [in Chinese]

1979b, Stratigraphy of the Hebei Sheng and Tianjin Shi: Beijing, China, Geological Publishing House, Regional stratigraphic tables of North China, v. 2, 228 p. [in Chinese].

Scientific Research Institute of Petroleum Exploration and Development, Ministry of Petroleum Industry and Institute of 
Geology and Paleontology, Academia Sinica, 1978, Early Tertiary gastropod fossils from coastal region of Bohai: Beijing, China, Science Press, 33 pls., 157 p. [in Chinese with English summary].

Shuai Defu, Qian Kai, Song Yongshen, and Ge Rong, 1984, Distribution of stratigraphic-lithologic pools in the Jiyang depression: Beijing Petroleum Geology Symposium, September 1984,13 p. [reprint].

Tang Zhi, 1979, Preliminary study on the forming condition of the oil and gas pools in the oil and gas field-bearing slope terrane of the Bohai Bay: Shiyou Kantan Yu Kaifa [Petroleum Exploration and Development], no. 2, p. 11-17 [in Chinese].

Tissot, B.P., and Welte, D.H., 1984, Petroleum formation and occurrence: New York, Springer-Verlag, 2d ed., 699 p.

Wang Hongzhen and Qiao Xiufu, 1984, Proterozoic stratigraphy and tectonic framework of China: Geological Magazine, v. 121, no. 6, p. 599-614.

Wang Shangwen, Zhang Wanxuan, Zhang Houfu, and Tan Shidian, 1983, Petroleum geology of China: Beijing, China, Petroleum Industry Press, 348 p.

Wang Xieqing, Li Ke, Lang Renchi, and Shang Huiyan, 1980, Biological marker hydrocarbons in source rock and crude oil of some Chinese basins: Acta Petrolei Sinica, v. 1, no. 1, p. 52-62 [in Chinese with English abstract].

Wood, G.H., Jr., Kehn, T.M., Carter, M.D., and Culbertson, W.C., 1983, Coal resource classification system of the U.S. Geological Survey: U.S. Geological Survey Circular 891, 65 p.

Wu, C.K., Wu, K.S., Gledhill, D.F., and Fei, A.C.Y., 1978, Chinese to English dictionary: Monterey, California, Chinese Language Research Association, 399 p.

Wu Huayuan and Liang Digang, 1984, Analysis on formation condition of three oil fields in Jizhong depression: Beijing Petroleum Symposium, September 1984, 22 p. [reprint].

Wu Zhenlin, 1982, A brief discussion on oil and gas pools in western Liaohe depression and their regularities of distribution: Oil and Gas Geology, v. 3, no. 2, p. 149-157 [in Chinese with English abstract].

Wu Zhenlin and Lu Jiuhua, 1983, Location of faults at Tanlu in the Liaohe depression and their control over oil accumulations of the region: Acta Petrolei Sinica, v. 4, no. 1, p. 17-22.

Xu Huaida, Lu Weiwen. Wang Shifeng, and Wan Jingping, 1983, Paleogene sedimentary systems and direction of searching for oil and gas in Bohaiwan basin: Acta Geologica Sinica, v. 57 , no. 3, p. 243-253 [in Chinese with English abstract].

Yan Dunshi and Zhai Guangming, 1981, Exploration practice in and prospects of the buried-hill oil fields in North China, in Mason, J.F., ed., Petroleum geology in China, principal lectures presented to the United Nations International Meet- ing on Petroleum Geology, 1980, Beijing, China: Tulsa, Oklahoma, Pennwell Publishing Co., p. 92-100.

Yan Dunshi, Wang Shangwen, and Tang Chi, 1980, Block faulting and formation of oil and gas fields associated with buried hills in Bohai Bay basin: Acta Petrolei Sinica, v. 1, no. 2, p. 1-10 [in Chinese with English abstract].

Yang Peisan and Li Gongzhi, 1980, Development of carbonate reservoirs in the Renqiu oil field: Acta Petrolei Sinica, v. 1, no. 4, p. 57-64 [in Chinese with English abstract].

Yang Zunyi, Cheng Yuqi, and Wang Hongzhen, 1986, The geology of China: New York, Oxford University Press, $303 \mathrm{p}$.

Zha Quanheng, 1984, Jizhong depression, China-Its geologic framework, evolutionary history, and distribution of hydrocarbons: American Association of Petroleum Geologists Bulletin, v. 68, no. 8, p. 983-992.

Zhai Guangming and Zha Quanheng, 1982, Buried-hill oil and gas pools in the North China basin: American Association of Petroleum Geologists Memoir 32, p. 317-335.

Zhang Fuming and Jian Zongyu, 1981, The sedimentation history and environmental characteristics of the early Tertiary in Huanghua basin: Oil and Gas Geology, v. 2, no. 2, p. 141-157 [in Chinese with English abstract].

Zhang Zhencai, Wang Zhongran, Chen Xianzhong, and Zeng Xianzhang, 1983, Gonanes and terpanes from crude oil and source rocks in Jizhong depression: Oil and Gas Geology, v. 4, no. 1, p. 89-99 [in Chinese with English abstract].

Zheng Changming, 1984, A new development on exploration of basement rock buried hill oil field in Liaohe faulted depression, China: Beijing Petroleum Symposium, September 1984, 16 p. [reprint].

Zhongyuan Petroleum Exploration Bureau, 1980, Structural outline map of the Dongpu depression: Puyang, Henan, Zhongyuan Petroleum Exploration Bureau, one sheet with composite columnar stratigraphic section, scale 1:200,000 [in Chinese].

Zhou Guangjia, 1981, Character of organic matter in source rocks of continental origin and its maturation and evolution, in Mason, J.F., ed., Petroleum geology in China, principal lectures presented to the United Nations International Meeting on Petroleum Geology, 1980, Beijing, China: Tulsa, Oklahoma, Pennwell Publishing Co., p. 26-47.

Zhou Xingxi, Yuan Rong, and Li Xuexin, 1985, Thermal evolution of the coal series of Late Paleozoic in southern part of North China and evaluation of its coal gas resources: Acta Petrolei Sinica, v. 6, no. 1, p. 31-40 [in Chinese with English abstract].

Zhu Jiawi and Xu Huazeng, 1984, Characteristics and origins of natural gas in Dongpu depression: Beijing Petroleum Geology Symposium, September 1984, 12 p. [reprint]. 

